\begin{tabular}{|c|c|c|c|}
\hline & $\begin{array}{l}\text { Escola Superior } \\
\text { de Gestáoe e } \\
\text { Tecnologia } \\
\text { [iPSantarém] }\end{array}$ & 掼 & $\begin{array}{l}\text { ISSN 2029-7564 (online) } \\
\text { SOCIALINĖS TECHNOLOGIJOS } \\
\text { SOCIAL TECHNOLOGIES } \\
2014,4(1) \text {, p. } 93-117\end{array}$ \\
\hline
\end{tabular}

\title{
VEIKLOS DUOMENŲ INTEGRAVIMAS: PROBLEMOS, YPATUMAI IR METADUOMENŲ SVARBA
}

\author{
Gražina Kalibataite \\ Kauno technologijos universitetas, Lietuva, kaligraz@elekta.lt \\ doi:10.13165/ST-14-4-1-07
}

\section{Santrauka}

Tikslas - remiantis moksliniu ir praktiniu studiju analize atskleisti bei pagristi, kad metaduomenys - gyvybiškai svarbus veiksnys, siekiant kokybiškos ir objektyvios veiklos duomeny integracijos.

Metodologija - literatūros šaltinių analizé - veiklos duomenu valdymo tikrovei ir šiuolaikèms integravimo reikmèms, problemoms atskleisti bei pažymèti metaduomenu valdymo svarba. Veiklos procesu, duomenu grafinis vaizdavimas - integruoto informacijos valdymo procesu aspektams bei metaduomenu valdymo ir taikymo uždaviniams pažinti, atskleisti.

Rezultatai - atskleistos priežastys, kodèl ịmonèse neracionaliai igyvendinami duomenu integravimo sprendimai ir kokias naujas integracines reikmes kelia šiandienos veiklos aplinka, skatinanti ieškoti efektyvesniu integravimo formu, pvz., metaduomenimis gristo integravimo. Galiausiai, atliktas praktinis (žmogiškuju ištekliu (ŽI) srities) tyrimas integracijos aspektu - ivertinti realūs duomenu valdymo ir integravimo aspektai, atlikus ŽI informacinès veiklos analizę.

Tyrimo ribotumas - rekomenduojami kai kurie galimi duomenu integravimo vykdymo gerinimo būdai.

Praktinè reikšme - atlikti teoriniai ir empiriniai tyrimai prisideda prie veiklos duomeny integravimo, ypač metaduomenimis grindžiamo, teisingo supratimo ir igyvendinimo stiprinimo. Rezultatai vertingi praktikams, nes pateikia šiuolaikišku žiniu, nauju ižvalgų, kurios atskleidžia savitas integruoto duomenu valdymo problemines 
situacijas ir veiksnius, veikiančius integracinius procesus, bei metaduomenu naudojimo duomenu integravimui pagristumą. Grafiškai atskleistos ir pavaizduotos ŽI informacinio valdymo situacijos - tai praktiné priemoné plètojant ŽI duomenu integravima.

Originalumas/vertingumas - atlikta literatūros apžvalga leidžia atskleisti aktualias ir tam tikras, nulemtas ịvairialypés įmoniu veiklos bei technologiju aplinkos, integruoto duomenu tvarkymo situacijas; tvirtinti, kad esminis veiklos duomenu valdymo aplinkos elementas - integracijos procesas - tapo svarbiu kasdieniu uždaviniu. Nustatyta, kad itin mažai darbu, kuriuose yra tiriamos duomenu integravimo efektyvumo didinimo galimybès, ypač metaduomenu aspektu. Darbe pateikta išsami metaduomenu valdymo taikymo teikiamos naudos analizé integracijos požiūriu bei pristatyti integracijos tobulinimui tinkami būdai, nukreipti i metaduomenu naudojima. Praktinis tyrimas teikia galimybę geriau pažinti ir savikritiškai įvertinti ŽI valdymo procesus, ju valdyma palaikančias IS (informacinius procesus) sąveikumo aspektu.

Raktažodžiai: duomenu integravimas, metaduomenys, squeikumas, informacinès sistemos, integracijos architektūra, veiklos modelis, žmogiškuju ištekliu valdymas, modeliavimas.

Tyrimo tipas: mokslo darbų ir praktiniu tyrimu apžvalga, empirinis tyrimas.

\section{Ivadas}

Šiandienos veiklos rezultatus lemia duomenų ir informacijos turinio kokybè, lai$\mathrm{ku}$ ir operatyvus duomenu integravimas, teikimas naudotojams. Duomenys tapo ne tik kasdieniu veiklos procesų valdymo įrankiu, strateginiu veiklos turtu, bet ir esmine verslo dalimi, informaciniu aktyvu, konkurencingumo raktu. Taigi, tinkamas duomenų rinkimas, dorojimas ir glaudi įvairių tipų vidaus, išorès duomenų integracija (Agrawal et al., 2008; Асадуллаев, 2010) - kelias, siekiant realaus veiklos ir veiksmų efektyvumo ir pelno.

Pastebima, kad konkurencinį pranašumą ilgainiui ţgis įmonès, kurios gebės nuolat peržvelgti ir kuo objektyviau ịvertinti, tobulinti darbinès veiklos informacinius modelius, technologijas, procesus (Nidumolu et al., 2009); pasirūpins informaciniu sistemų (IS) reorganizacija, operatyviu ir logišku praktiniu jų taikymu, ịvairių duomenų integracija (Замятина et al., 2013). Nūdienos praktinis duomenų valdymas pasižymi nevienalyčių, silpnai struktūruotų ir nestruktūruotų duomenų srauto ịvairove ir gausa. Lemiamas vaidmuo tenka duomenų modeliui, kuris daugelyje IS - reliacinis nèra gerai išplètotas; dažnai yra subjektyvus, nevienareikšmis, todèl negali objektyviai ir lanksčiai spręsti didumą integravimo, intensyvių veiklos užduočių. Dažnu atveju veiklos valdymo IS nèra vienalytès. Atskirai diegiamos analitinio duomenų dorojimo ir operatyvinio valdymo, kitos IS. Kiekviena realizuoja tik tam tikrą veiklos logiką (Кашников ir Лядова, 2011; Микляев, 2010). Atkreiptinas dèmesys, kad tradicinès IS dirba su duomenimis ir veiklos žinių nepadeda atskleisti ar ịvertinti, nes trūksta veiksmingų duomenų integravimo sprendimų (Хитрова, 2010). Daug taikomụjų duomenų yra ịvairiuose nestruktūruotuose (ịstatai, nuostatai, reglamentai, taisyklès) 
dokumentuose (Ланин et al., 2012). Todèl šiuolaikis darbas su informacija turi atsisakyti tik reliacinių duomenų naudojimo ir pereiti prie mažiau struktūruotų duomenų valdymo technologijų, nukreiptų (kontroliuojančių) i̇ i̇monių praktinę veiklą, leidžiančių formalių modelių naudojimu (arba metamodeliavimu) grịstą IS kūrimą, jų keitimą bei užtikrinančių informacinių bazių ir duomenų restruktūrizavimą, metaduomenimis (toliau - MD) grindžiamą integravimą (Baars ir Kemper, 2008; Nagy ir Tolea, 2011; Еркимбаев et al., 2010; Лядова, 2012; Замятина et al., 2008). Tuоmet MD, susiję su veiklos informacija ir leidžiantys suformuoti lankstų konceptualu duomenų modeli, aprašyti IS aspektus ir jos taikymo sriți, užtikrinti duomenų srautų tarp skirtingų duomenų šaltinių integravimą ir valdymą (Mhashilkar ir Sarkar, 2009; Еркимбаев et al., 2010; Лядова, 2008), kokybiškus duomenis (Dong ir Naumann, 2009; Marotta et al., 2010; Shankaranarayanan et al., 2006; Асадуллаев, 2010), veiksmingiau valdyti ir tureti veiklos žinių (Verbitskiy ir Yeoh, 2011), tampa svarbūs tiek pat, kiek ir duomenys.

Svarbūs tikslai valdant šiuolaikę ir vis atviresnę informaciją, i̇vairias šaltinių formas - tai naudoti, derinti ir (ar) integruoti ne tik pirmines struktūruotas duomenu bazes (DB), bet ir iš dalies struktūruotus, neskaitmeninius duomenų rinkinius, išskirstytus ịvairiose saugyklose (Кашников ir Лядова, 2011); atsisakyti formaliai suplanuotos duomenų integracijos, nurodančios tik duomenų šaltinius, bet neapibrèžiančios jų integravimo turinio (t. y. neteikiančios objektui žinių, o vartotojams - pasitikẻjimo duomenimis). Šios tendencijos formuoja naują duomenų integravimo valdymo priemonių ieškos mokslinių tyrimų reikmę, stiprina prielaidą, kad informacijos MD suvokimas ir valdymas - esminis aspektas, siekiant tureti pakankamos kokybès ir darnios veiklos informacijos - turi būti nagrinèjamas kaip sudedamoji informacijos integravimo, keitimosi ir valdymo dalis.

Ivairiarūšių veiklos procesų, duomenų integravimo problemas ir MD vienetų naudojimo galimybes, teikiamą svarbą ir skvarbą, naudingumą integravimo ar atskiriems veiklos procesams savo darbuose plačiau ar glaustai tyre ịvairūs mokslininkai, praktikai (Baars ir Kemper, 2008; Becker et al., 2003; Berthold et al., 2010; Folinas, 2007; Göres et al., 2009; Hallett, 2004; Kilpeläinen ir Nurminen, 2007; Mhashilkar ir Sarkar, 2009; Pant, 2009a; Rahman et al., 2012; Sen, 2004; Verbitskiy et al., 2009; Vnuk et al., 2012; Wik, 2011; Асадуллаев, 2009, 2010; Богданов ir Куликов, 2007; Вигурский ir Пивоваров, 2008; Кашников ir Лядова, 2011; Михайлов, 2009; Хитрова, 2010; kt.). Nepaisant to, yra daug sunkumų integruojant veiklos duomenis ir taikymus, ịvairių neatsakytų klausimų dèl MD lygmens teikiamos naudos integravimo (informacijos kūrimo) procesams. Menkas dèmesys skiriamas informacinių išteklių integravimo procesams, kurie realiai įvertintų įmonių veiklos savitumus, sparčiai kintančius veiklos bruožus ar konstruktyviai reaguotų ị organizacinių, darbo pokyčių turinį; taip pat naudotojų informacinio aprūpinimo gerinimui šios integracijos pagrindu.

Tyrimo objektas - veiklos duomenų integravimo procesas metaduomenų aspektu.

Tyrimo tikslas - teoriškai ir empiriškai ištirti veiklos duomenų valdymo ir integravimo problemas, atskleisti metaduomenų valdymo teikiamą naudą ir teigiamą itaką kokybiškam integravimo procesų vykdymui. 


\section{Požiūrių ir problemų i integruotą veiklos duomenų valdymą analizè}

Daugelio tyrejjų, praktikų įžvalgomis pažymètina, jog veiklos ir valdymo procesų, duomenų kokybè tiesiogiai priklauso nuo informacinių technologijų (IT) teikiamų galimybių, jų integravimo ị veiklos ir darbo technologinius procesus užtikrinimo. Interpretuojant tyrimą (Atkočiūnienè ir Juškaitė, 2012), verta atsižvelgti ị tai, jog efektyvūs veiklos procesai, jų valdymo stiprinimas galimas tik maksimaliai integruojant IT, kurios padètų suprastinti kasdienes įmonių rutinas ir procedūras, palaikytų visavertị atskirų funkcinių padalinių tarpusavio informacinį bendradarbiavimą.

Kaip žinoma, taikomųjų sričių procesai, kurie aprašomi DB, kaip ir visos gyvos sistemos, nuolat keičiasi (Микляев, 2013). Imonių veikla pasižymi procesų ir veiklų, jų turinio ir sudèties (pvz., matavimo vienetų, informacijos šaltinių) įvairove, todèl informacinè veikla igyja savitų bruožų ir kartu formuoja sudètingą informacijos ištekliụ (loginę) struktūrą, įeinantị / išeinantị duomenų srautą. Pvz., tyrime (Dassistil et al., 2006) pažymima, kad integruojant taikomąsias veiklų vykdymo ir procesų valdymo programas, gamybos procesus ir naujas veiklas, vertintini ịvairūs aspektai: informacijos struktūra ir jos mainų procesai, siejami su konkrečia veikla, taikomųjų IS naudojimo ir veiklos funkcijų atlikimo ypatumai. Manoma (Franklin et al., 2005), kad didelę reikšmę turi suformuota konkreti duomenų erdvè ir svarbi visa įmonès veiklos informacija, neatsižvelgiant ị gavimo / teikimo formą (pvz., sąrašųu, lentelių, grafikų, analitinè), šaltinio buvimo vietą, struktūrą. Be to, trumpèja produktų ir paslaugų gyvavimo ciklai, o tai verčia greitai keisti veiklos valdymo modelius ir pritaikyti IS (Bara et al., 2009; Rudzkienè ir Kanopka, 2011); laikytis veiklos strategijos, taisyklių ir kartu spręsti duomenų, schemų, versijų palaikymo ar būdingas problemas (pvz., naujų duomenų objektų naudojimo, duomenų kūrimo ir teikimo atvejų, formatų saugojimo) (Agrawal et al., 2008).

Kartu pasakytina, jog nors įmonių darbuotojai tikisi vis išsamesnių ir naujausių duomenų su veiklos turiniu, bet įmonès negali tenkinti šiu reikmių, nes plečiantis informacijos srautui, sunku išvengti itin aštriu problemu, pvz.: integracijos procesuose spèti fiksuoti realius loginius-semantinius ryšius tarp duomenų (Qin ir Prado, 2006); greitai rasti ir naudoti naujus duomenų šaltinius, nes globali integravimo schema sunkiai vystoma, išplečiama; ribotos schemos ir ịrašų derinimo technikų galimybés, žinant tai, jog duomenys ir MD dažnai yra specifiški ir duomenų ekspertai turi pašalinti dviprasmiškumus (Yan et al., 2013); greitai auga organizaciniai duomenys (ir blogesnès duomenų kokybès rizika) (Shankaranarayanan et al., 2006); keičiasi ir randasi nauji duomenų reikalavimai, saugojimo formos, struktūra ir tikslumas, todèl reikia išankstinio dorojimo, kad duomenys būtų integruoti ir taptų tinkami naudoti (Verbitskiy ir Yeoh, 2011). Dẻl šių ir kitų priežasčių vèluojama apibrežti išeigos srautą (rezultatą: ekranines formas, ataskaitas, duomenų srautus el. formatu), patogiu ir suderintu formatu rengti, teikti duomenis įvairiems skaičiavimams, analizei atlikti. Taigi, pasak (Baars ir Kemper, 2008), audringa ir globali darbo veiklos aplinka, veikiama rizikos, apsunkinta valdymo kaitos (naujovių), susipynusių procesų, - tai ịprastiné veiklos procesų situacija. 
Tyrimai rodo, kad integruotas duomenų tvarkymas kelia problemas, apie kurias beveik nekalbama ir nuodugniau neapmąstoma; įmonèse trūksta kompleksinio, integruoto duomenų valdymo požiūrio, tinkamo IS taikymo įmonių veiklos tikslams (1 pav.).

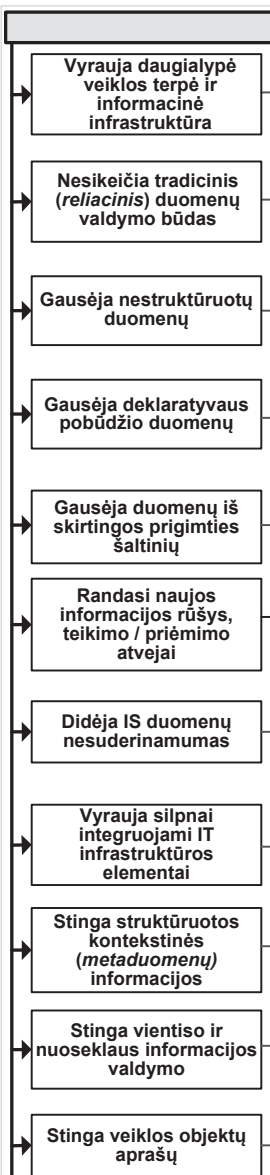

Didèja integracijos sudètingumas

Sukaupta daugybé duomeny

Naudojami skirtingi formatai

Stinga supratimo apie informacijos valdymo apliną ir srities duomenis

Siūlomi daugiašaltiniai, išskirstyti duomeny rinkiniai

Duomenų dezintegracij

\section{Integruoto informacijos tvarkymo probleminès situacijos}

Paprastai ịmonèse esti situacija, kai (1) naudojamos javairu tipu ir jvairių gamintoju IS bei technologinès priemonès atsitiktinés architektūros: (2) išplèstinè duomeny ieška dèl skirtingu sąvoku ir taksonomijos (semantikos ir struktūros) yra sudėtinga, o (3) procesai nėra valdomi arba iš naujo naudojami pasinaudojant metaduomenimis. Dèl to neigiama veikiama veikla: sunku rasti išskirstytą informaciją, derinti duomenis (jų versijas) ir užtikrinti duomenų kokybę $>$ Hallett, 2004

Diduma veiklos valdymo sistemu, grindžiamu tradiciniu reliaciniu duomenu modeliu, nėra pakankamai naudingos ir patikimos, leidžiančios tinkamai spręsti šiuolaikès veiklos ir procesu valdymo uždavinius - skirtingo pobūdžio užduotims reikia skirtingu duomenu teikimo modeliu. Dël to kyla ivairu tipu išskirstytu duomenu (arba skirtingu duomenų modelių) integravimo, analitinio dorojimo bei duomenų operatyvaus valdymo palaikymo problemos

Кашников ir Лядова, 2011

Imonès turi didelius kiekius struktūruotụ duomenų, susietụ su nestruktūruotais (pvz., dokumentai, el. paštas) duomenimis. Todël reikia integruoti nevienarūšius veiklos procesụ elementus, tokius kaip: duomenis, organizacinius vienetus, skirtingus technologinius ir informacinius srautus bei kitus informacijos objektus

Agrawal et al., 2008; Carpinetti, 2003

Randasi vis daugiau deklaratyvaus podūdžio duomenu. Naudotojai nori nesudėtingo jivairiu duomenu bei vidaus, išorès informaciniu aplinku susiejimo, paprastu duomeny jvesčiu formu ir vedliu. Todèl reikia pertvarkyti ir kurti savas sistemy architektūras, pvz., duomenu ir taikomuju uždaviniu integravimo, duomenų iš turimu $D B$ i naujas DB migravimo, informacijos ištraukimo, DB naršymo ar laikinụjų užklausų vykdymo

Agrawal et al., 2008

Gausèja duomenu, kylančiu iš skirtingos prigimties šaltiniu, dažniausiai ne iš tradiciniu DB (pvz., txt, Word, Excel, xm failu ir kt.). Dël šios priežasties reikia metody, priemoniu ir sisteminiu komponentu, kurie padètụ rinkti, perduoti, keisti, teikti ir centralizuotai valdyti ịvairių šaltinių bei veiklai reikiamus duomenis

Agrawal et al., 2008

Su kiekviena diena auga priimamos, perduodamos, dorojamos ir saugomos informacijos srautas, IS kiekis bei keičias ieinančio srauto struktüra. Randasi naujos informacijos rǔšys ir darbo su jomis priemonès. Skirtingus procesus ir didel objektų kieki sudètinga susieti

$>$ Вигурский ir Пивоваров, 2008

Duomenu integracija susiduria su dviem esminiais sunkumais. (1) Duomenys iš skirtingụ šaltinių yra dažna nevienalyčiai. Nevienalytiškumas gali rastis duomeny schemos lygmenyje, nes duomenys (metaduomenys) skirtingose sistemose arba skirtingose dalykinèse srityse yra skirtingai suvokiami, o skirtingi duomenu šaltiniai dažnai apibūdina tą pačią sriți, naudodami skirtingas schemas. (2) Skirtingi šaltiniai gali tiekti prieštaringus duomenis (nepilnus, klaidingus ar pasenusius)

Dong ir Naumann, 2009; Giovinazzo, 2009

Dabartinè įmonių IS erdvė pasižymi architektūrụ ir technologiju jivairove. IT infrastruktūrą sudaro silpnai integruojami, veikiantys skirtingose technologinèse platformose ir parašyti skirtingomis programavimo kalbomis, elementai, 0 prieiga prie jų vykdoma naudojant daug skirtingu (nepatogių) vartotojų sąsajų

Климов, 2011

Imonés kasdien generuoja ir doroja didelès apimties duomenis, gautus iš jivairiu veiklu ir procesu. Šiuos duomenis doroja platus spektras kompiuteriniu sistemu, kurios patiria kontekstinès (kaip tikslios, patikimos ir realaus laiko šaltinių) informacijos stygiụ

\section{Folinas, 2007}

Daugelyje imoniu, ypač kai padaliniai veikia kaip specializuoti ar išskirstyti atskiri funkciniai vienetai, nėra vientiso informacijos valdymo. Vykstantys heterogeniniai procesai ir skirtinga IS prigimtis trukdo tinkamai naudoti turima informacija. Todėl randasi klientu aptarnavimo problemos, nes trūksta savalaikiu ir nuosekliu produkcijos gamybos duomenu

Kilpeläinen, 2007; Kilpeläinen ir Nurminen, 2007 Iprastai įmonės neturi apibréžtų (DB, žodynuose) pagrindinių veiklos objektų, jų aprašų ar paskelbtų žinių apie veiklos objektus visoje įmonèje. Todèl sunku užtikrinti kompiuterini ir informacinį bendradarbiavimą tarp veiklos klientų if partnerių, veiklos procesų aktorių, sistemų naudotojų

Hüner et al., 2011 Imonių sistemų architektūra gana stichiška. Integracijos sudėtingumą taip pat didina tai, kad duomenys gaunami iš šaltinių, turinčių skirtingus modelius arba turi skirtingą semantiką, t. y. skirtingai interpretuojami šaltiniai

$>$ Хитрова, 2010

Tobulèjant IS ir internetui, jmonės sukaupė daug duomenu. Tačiau kadangi skiriasi sukūrimo motyvai, gavimo šaltiniu veiklos ir funkcijos (veiklos sritys) bei lygmenys, akivaizdu, kad informacija igijo rimtu problemu, kliudančiu dalytis ir naudotis informacija (pvz., prieštaringi duomenų apibrèžimai, dvigubinami duomenys, IS segmentuotos ì sritis)

Zhang et al., 2010

!prastai, skirtingi specialistai net vienos srities viduje, tarpusavio bendravimui naudoja skirtingus formatus. Duomeny ivairiarūšiškumą lemia skirtingi vietiniai apibréžimai (atributụ tipai, formatai ar tikslumas), o semantinj nevienalytiškumą (ar skirtingumą) gali įtakoti įmonès vietinių duomenų prasmès ir naudojimo skirtumai ar panašumai

Blue et al., 2011 Atskirtis tarp veiklos ir techninių naudotoju nemažèja. Telkiamasi i technologines problemas, neivertinant veiklos
aplinkos aspektu. Prižiūrèti duomenu rinkinius iš daugelio atskiru duomeny šaltiniu yra problema, nes diduma aplinkos aspektu. Prižiūrèti duomenų rinkinius iš daugelio atskirų duomenu šaltiniụ yra problema, nes diduma
naudotojų nèra susipažinę su tais duomenimis. Skirtingi padaliniai ir skyriai įmones viduje tas pačias sąvokas supranta naudotoju nera susipažinę su tais duomenimis. Skirtingi padaliniai ir skyriai įmones viduje tas pacias sąvokas supranta
skirtingai, taip pat bendradarbiaujančios įmonès ir išorès organizacijos

Faktas, kad šiuolaikiai taikomieji paketai ir procesai, naudojami šiuometinėse įmonėse, siūlo išskirstytus duomenu rinkinius. Daugialypiai duomenu šaltiniai sistemose ir informacija, pasklidusi skirtinguose ir ịvairiarūšiuose šaltiniuose bei tai, kad neimanoma pilnai suprasti pasiekiamos informacijos, reikalauja valdyti integruotai

Hassine ir Laboisse, 2011

Imonėse gausu jvairiu technologijų IS ir j̧rankiụ, pasižyminčiu skirtingomis savybėmis ir tikslais. Kiekviena sistema renka ir laiko informacija nesançia niekur kitur. That metu yra užduočiy kurioms reikia duomenu iš keliy duomeny šaltiniu (tiek vidaus, tiek išorés), kurie dažnai nera suprojektuzti ir pritaikyti dirbti kartu _ ną kelị duomenu $\begin{aligned} & \text { šaltiniu (tiek vidaus, tiek išorès), kurie dažnai nèra suprojektuoti ir pritaikyti dirbti kartu - tai lemia duomenu } \\ & \text { dezintegraciją }\end{aligned}$
Hristov, 2012; Микляев, 2013

1 pav. Integruoto informacijos tvarkymo probleminès situacijos 
Ivardytas problemas, aptartus atvejus (1 pav.) sunkina ir tai, kad sudètingejjant imonių reikmėms (veikloje auga situacijų, išimčių ịvairovè) ir augant duomenų kiekiui, duomenų dorojimas ir analizè reikalauja ne tik spartesnès įrangos, naujų priemonių, didesnių saugojimo kaštų, bet ir tampa sudètingi: 1) İmonių operacinèse DB sukauptos žinios, apie kuriu buvima naudotojai gali nežinoti (Hassanien et al., 2009). Veiklos ir technikos srityse kyla nauji uždaviniai, todèl naudotojai, norintys teisingai taikyti IT, turi jas suprasti. Tai nèra lengva, nes kai kurie algoritmai yra sudètingi; 2) Veiklos sprendimų kūrëjai ne visuomet supranta sprendimu turinį, todèl jie būna subjektyvūs (Shankaranarayanan et al., 2006). Dažnai neįvertinami duomenų turinio veiksniai, kurie lemia duomenų kokybės suvokimą (pvz., užduotys, kurių duomenys panaudoti, ar asmens, priimančio sprendimus, darbinès veiklos igūdžiai); 3) IS naudotojai tiksliai nežino, kokiais duomenimis grịsta ju veikla (Manegold et al., 2009). Šiuolaikès IT priemonès, naudojamos darbe ar veikloje, sudètingos. Tuo tarpu ne visi naudotojai supranta fizini DB projektavimą, indeksų pasirinkimą, MD naudojimą ar turi geras SQL (užklausų kalbos), kitas prièjimo prie duomenų, jų tvarkymo ir analizès žinias, leidžiančias DB objektų naršymą, ataskaitų ir diagramų apibrěžimą, duomenų filtravimą, t. y. padedančias racionaliau naudoti kasdienius duomenis, kokybiškiau atlikti informacinès veiklos operacijas.

Praktikoje veiklos organizavimo sprendimai sudaromi remiantis ịvairiais, ne tik reliacinėmis DB grịstais, informacijos nešejjais: apskaitos registrais, įmonės tikslais, taisyklėmis, vidaus tvarkomis, procedūromis, kitais apyvartos dokumentais. Pvz., tyrimuose teigiama, kad:

- Informacija neefektyvi ir nepritaikoma (Киреeва, 2008), nes dažnai įmonių vadovai gauna nepakankamą (ar perteklinę), pavèluotą ir netikslią informaciją, todèl negali suvokti darbo veiklos;

- Informacija neatitinka veiklos reikmiu ir neimmanoma priimti sprendimų realiu laiku, nes jie grindžiami gausiu (nebūtinai aiškiu, išsamiu) informacinių ataskaitų srautu (Bara et al., 2009); nes vartotojai gali užmiršti kai kurias veiklos reikmes ir reikalavimus, o IT vystytojai neteisingai suprasti juos ar jie negalëjo būti igyvendinti dèl laiko, išteklių stokos (Verbitskiy ir Yeoh, 2011);

- Gaištamas laikas informacijos atpažinimui. Išeities duomenų naudotojai priversti gaišti laiką relevantinès (kaip sprendimų prièmimo) informacijos ieškai, rinkimui, gretinimui ir koregavimui rankiniu būdu (Бубарева ir Попов, 2009) bei duomenų valymui, taikymui sprendimų reikmèms (Jain ir Thomson, 2013);

- Gaištamas laikas duomenu sklaidai (Jurkowski ir Slowinski, 2007). Skirtingos IS negali laisvai dalintis duomenimis, todèl randasi kliütys, dèl kuriu reikia didesniu naudotoju pastangu įvedant duomenis, priimant tinkamus sprendimus;

- Nesusimąstoma, kad gaištamas laikas (Карабанова, 2012). Dažnai darbuotojai gaišta laiką perkeldami tuos pačius duomenis ị skirtingus registrus, ịvesdami duomenis (ar kontroliuodami) $\mathfrak{i}$ kelias skirtingas IS, neintegruotas tarpusavyje.

Aptartame kontekste būtinas integruotas duomenų valdymas, nes be informacinès integracijos sistemos tampa ne tokios funkcionalios ir lanksčios, sunku išvengti nereikalingų duomenų ir procesų (dvigubinimo), bet atsižvelgiant ị realią įmonės 
duomenų erdvę, nustatytą vidaus tvarką ir uždavinius, sukauptą valdymo patirtị ar žinias. Beje, tyrimuose (Kilpeläinen ir Nurminen, 2007; Kilpeläinen, 2007) ižžvalgiai pažymima, kad daug svarbios informacijos, grịstos faktiniais duomenimis ir veiklos elgsenos žiniomis, kylančiomis iš gamybos procesų, slypi pačiuose gamybos ir veiklos procesuose. Todèl tik gerai pažįstant dalykinę sritį, jos procesus, duomenis ir eliminavus trukdžius (pvz., nustačius išoriškai nematomas procesų taisykles), randasi galimybẻ didinti integracijos lygit tarp sistemų ar veiklos subjektų. Pritartina (Agrawal et al., 2008), jog audringas duomenų kiekio, jų naudojimo atvejų bei programinių priemonių, platformų augimas verčia vis daugiau dèmesio skirti struktūruotų ir nestruktūruotų duomenų loginiams tarpusavio ryšiams nustatyti, analizuoti ir palaikyti; skatina ieškoti ar kurti naujus specializuotus veiklos duomenų valdymo sprendimus.

\section{Integruoto informacijos tvarkymo reikmių aspektai}

Naujajai veiklos valdymo praktikai būdinga naujų organizacinės struktūros funkcinès sandaros formų plètra, institucijų partnerystès, tarpusavio sąveikos integraciniai procesai. Tokioje situacijoje prioritetinèmis dimensijomis tampa įmonių tarpusavio integracija, informacinès sklaidos jungtys (Bučinskas et al., 2013). Taip pat pagrịstai manoma (Folinas, 2007; Yeoh ir Koronios, 2010), jog informacijos ir veiklos vertè išauga, jei gerai integruojami ir valdomi visi darbo duomenys, informacija, žinios. Taigi, be duomenų integracijos įmonès negali išgyventi.

Integruotas veiklos valdymas ịprastai grindžiamas informaciniu požiūriu ir valdymu. Integruoto valdymo (informavimo) elementais yra objektai, procesai ir parametrai, apibūdinantys patị valdymą, veiklos rezultatus (Булгаков ir Корнаков, 2010). Tyrèjų (Verbitskiy et al., 2009) vertinimu, esminis veiklos informacijos valdymo aplinkos elementas - integracijos procesas - nuolatinis duomenų kèlimas iš skirtingu šaltinių í vieną integruotą vietą ir kaupimas, teikimas naudotojams. Šis procesas siekia svarbių tikslų: didinti duomenų, kuriuos gauna vartotojai ir taikomosios IS, pilnumą, glaustumą ir funkcinį tinkamumą (Dong ir Naumann, 2009); gauti faktinių veiklos žinių (Hassine ir Laboisse, 2011). Juo vis labiau domisi veiklos analitikai, žinių darbuotojai ir eiliniai IS ar jos dalių naudotojai, siekiantys sprendimus grịsti ne pavieniais duomenų šaltiniais, bet žiniomis apie valdomą objektą (Becker et al., 2003; Mödritscher et al., 2007; Rahman et al., 2012; Хитрова, 2010).

Pastarojo meto glaudesnè integracija verčia spręsti problemas, kurias lemia dinamiška, îvairialypè veiklos ir technologijų aplinka, saviti informacijos vienetai (padaliniai, skyriai, veiklos) (Agrawal et al., 2008; Кашников ir Лядова, 2011) ar išskirstyta veiklos gamyba, kurios sudetingus vienetus (esybes) reikia valdyti kaip visumą (Kilpeläinen ir Nurminen, 2007). Pabrèžtina, kad įmonės turi komercines IS, kurios ne tik ignoruoja įmonių veiklos valdymo taikymo patirtị ir jose trūksta lanksčiai keičiamų veiklos procesų, bet ir pasižymi gausiu, bet beveik nenaudojamu ir neišnaudojamu funkcionalumu, ribotomis operacijų atlikimo, duomenų keitimosi ir analizès galimybėmis. Be to, mokslininkai (Stankevičienė et al., 2007) pažymi, jog šiuolaikinėje įmonèje sistemų integracija yra santykinè, nes keičiasi veiklų santykiai, o atskiros sistemos kuriamos skirtingu laiku, todèl reikia jungti informacinius srautus, užtikrinančius 
unifikuotą informacijos perdavimą ir prièmimą. Mokslininko (Карабанова, 2012) požiūriu, ịmonès architektūra (kaip integracinè) turi sieti ịvairius, veiklą lemiančius elementus: veiklos procesus, duomenis, programinius paketus, technologijas ir MD. Pagal (Завьялова, 2011), veiklos sprendimams priimti tinka struktūruoti ir nestruktūruoti duomenys. Todèl, norint turèti greitai pasiekiamos, darnios ar anksčiau nežinomos, bet potencialiai naudingos veiklos informacijos, reikia duomenis išgauti, atrinkti ir integruoti (eksportuoti / importuoti, išsaugoti) i informacines saugyklas. Kituose darbuose (Folinas, 2007; Jucevičius ir Ilonienè, 2009; Nagy ir Tolea, 2011; Zhang et al., 2010; Булгаков ir Корнаков, 2010; Семенов ir Татаринцев, 2011) dar kartą irodoma, jog ten, kur vyksta bent dviejų negiminiškų sistemų sąveika ir reikia žinoti visumini veiklos (operatyvinio lygmens) vaizdą ir erdvę, būtina integruoti kitų funkcinių sričių ir šaltinių duomenis, žinias, informacinès kilmès veiklos procesus ir juos palaikančias IS, integruoti naują informaciją su jau turimomis žiniomis.

Teigtina, jog daug naudingų duomenų niekada nepatenka ị analizę ir todèl iškreiptai suvokiama faktinè veikla, priimami netikslūs valdymo sprendimai (Berthold et al., 2010). Tirti darbai ịrodè, kad duomenų integracijos projektai neaprūpina naudotojų kokybiškais duomenimis. Priežastys: ne tik praktinių integracinių pasiūlymų nebuvimas (Hassine ir Laboisse, 2011), išplèstinių žinių apie duomenis integravimo metu stoka (Егошина ir Вороной, 2011), programinès įrangos nelankstumas, didelès investicijos, bet ir blogai suformuota duomenų kokybès kèlimo tvarka ir procesai, informacinès patirties ir kantrybès trūkumas siekiant integracinès veiklos rezultato (Асадуллаев, 2010). Šiuo atveju duomenų kokybès užtikrinimo (sèkmès) įrankis veiklos MD.

Integracijos tyrèjų manymu, svarbus žmogaus veiksnys (Candan et al., 2008; Yan et al., 2013). Visų pirma, integracijos projekto darbuotojai, dirbantys su skirtingomis IT platformomis, daugialypès terpès sąsajomis ir liktinémis IS, turi turèti plačius igūdžius, technines ir veiklos žinias (Yeoh ir Koronios, 2010), o MD specialistai - gebéti rinkti, integruoti ir skelbti bendrus aprašomuosius MD ịvairiomis programomis, i̇rankiais (grafinio modeliavimo, integracijos, analizès), nes MD ir MD operacijos yra pernelyg ịvairūs, kad būtų tvarkomi vienu įrankiu (Burton et al., 2006; Göres et al., 2009). Kuriant veiklos MD ir dirbant su jais, reikia naujo mąstymo ir darbo požiūrio. Deja, darbuotojai priešinasi, nes turi keistis įsisenėję darbo procesai (Султанова, 2011). Praktikoje įmonių darbuotojai nepasirengę informaciją priimti vien el. formatu ir kompiuteriniais tinklais, negeba valdyti el. išteklių (Богданов ir Куликов, 2007). Integracijos realizacija (duomenų aspektai, veiklos taisyklès, MD, duomenų turinys) reikalauja realios informacijos, kurią gali teikti tik pagrindiniai IS naudotojai (Yeoh ir Koronios, 2010), o ekspertai ir taikomųjų sričių specialistai turi aktyviai dalyvauti ne tik IS aplinkos analizès (modelių kūrimo) ar projektavimo etapuose, bet ir viso naudojimo metu (Лядова, 2012).

Akivaizdu, kad su integracija susiduria visos įmonės. Svarbiu kasdieniu uždaviniu tampa veiklos IS duomenų (arba sistemų) integracija iš vienos rūšies ị kitą, su kitomis sistemomis bei išorès duomenų teikejjais palaikymas (Булгаков ir Корнаков, 2010; Рычков, 2009; Семенов ir Татаринцев, 2011); kuo didesnè integracijos orientacija i realią ímonių veiklą ir $\mathfrak{i}$ aktyvų duomenų naudotojų ịtraukimą ị integraciją. Siekiant integruotos informacijos sprendimų prièmimui, būtinas tvarkingas informacijos val- 
dymas, grịstas plačiai išsklaidytais duomenų šaltiniais ir apimantis gerai struktūruotą kiekybinę, iš dalies struktūruotą kokybinę ir vidaus, išorès informaciją (Becker et al., 2003). Taigi, aktualios technologijos ir programiniai - techniniai sprendimai, integruojantys ívairias veiklos automatizavimo ir valdymo palaikymo priemones, kurios paverstų duomenis (sukauptus IS) informacija, žiniomis ir tenkintų sprendimų reikmes (Замятина et al., 2013); galintys nuolat palaikyti ir plètoti DB ir IS integraciją, vienodą ir lanksčią prieigą prie centralizuotų duomenų; teikiantys galimybę formuoti tinkamai agreguotą informaciją, siekiant racionalios einamosios operatyvios veiklos analizès, ilgalaikio planavimo ar prognozavimo (Бубарева ir Попов, 2009).

\section{Metaduomenys - esminis šiuolaikès informacijos integravimo valdymo atributas}

Efektyvus duomenų, DB ir kitų veiklos informacijos šaltinių valdymas neatsiejamas nuo metaduomenų sąvokos. (Farrokhi ir Pokoradi, 2013; Execution-MiH, 2013) pagrịstai atkreipia dèmesĭ, kad nūdienos situacijoje veiklos kokybę lemia keli veiksniai: sistemos kokybė, informacijos kokybè, sistemos patikimumas, techninè struktūra ir MD valdymas.

Kaip tvirtina oficialūs šaltiniai, MD - tai duomenys, kurie apibrěžia ir aprašo kitus duomenis, ryšius tarp objektų; teikia informacinių objektų savybes ar ypatybes, skirtas jų turiniui apibendrinti, o tiksliau - papildomą prasmę ir naudą informacijai. MD integracijos procesu fone - tai visokie duomenys, teikiantys informaciją apie integruojamus vienetus ir duomenis, apie procesus ir priemones, ịtrauktus ị integruotų duomenų gavimą, tvarkymą ir naudojimą. T. y. svarbus struktūruotas integruojamų objektų požymių, informacijos šaltinių (pvz., reliacinių, objektinių, silpnai struktūruotų) schemų, informacinès aplinkos, duomenų struktūrų, tipų, formų ir kitų integravimo ypatumų (antrinès informacijos) aprašymas. Remiantis šaltiniu (Wik, 2011), $M D$ informacijos valdymo sistema - įrankis, padedantis spręsti semantinị nesuderinamumą, tikrinti duomenų srautų vientisumą ir kontroliuoti, valyti ar atmesti netinkamus įrašus, konsoliduoti ir jungti referentinius (realaus turinio) duomenis. Kokybiški $M D$, panaudoti informaciniuose procesuose, leidžia patikrinti duomenų, gaunamų iš veiklos procesų, kokybę (Verbitskiy ir Yeoh, 2011) ir ịvertinti duomenų kokybę darbinių užduočiu kontekste, o sprendimų prièmimo metu - teikia naujų duomenų turinio (pažinimo) žinių, duomenų turiniui savarankiškumo (Shankaranarayanan et al., 2006), t. y. kontroliuoja sprendimų rezultatus (iliustruota 2 pav.).

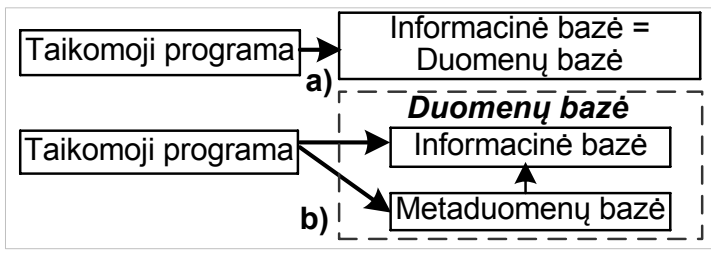

2 pav. Prieigos prie duomenų atvejai:

a) tradicinis (senasis); b) naudojant MD (sudaryta autorès) 
Analizuojant aptartus MD daromos ittakos, teikiamos naudos aspektus (3 pav.) pažymètina, jog duomenų integracijos požiūriu MD siejami su šiais tikslais: apibrèžti duomenis, užtikrinti kokybę, žvalgyti ir įrodyti kilmę ar šaltinị.

\begin{tabular}{|c|c|}
\hline \multicolumn{2}{|r|}{ o teikiami naudos aspektai } \\
\hline \multirow{2}{*}{$\begin{array}{l}\text { Informacinei infrastruktūrai plètoti ir palaikyti } \\
\text { (Hert, 2004; Vnuk et al., 2012) } \\
\text { Metaduomenu valdymas - informacinés infrastruktūros esminis } \\
\text { komponentas. Metaduomenu valdymo sistemos užduotis - padèti palaikytij } \\
\text { procesus ir juos automatizuojančias IT taikomassias programas; integruoti ir } \\
\text { derinti ivairiu sistemy veiklas (duomenis) bei užtikrinti veiksmingą ju kontrolę } \\
\text { ir valdymą, t. y. padéti dinamiškai prisitaikyti prie kaitos }\end{array}$} & $\begin{array}{l}\text { Tvarkai info } \\
\text { Metaduomenys - bū } \\
\text { tvarka informacijos } \\
\text { klasifikacijas ir struk } \\
\text { naudingesnès informa }\end{array}$ \\
\hline & Suvienodinti veiklos sa \\
\hline \multirow{2}{*}{$\begin{array}{l}\text { Veiklos procesu ir taikomuju paketu integravimui (Taylor, 2004) } \\
\text { Sékmingas veiklos procesu ir taikomuju paketu integravimas priklauso nuo } \\
\text { to, kaip bus integruoti i sistemą duomenys, priklausantys skirtingiems } \\
\text { duomenu šaltiniams, failu formatams ar duomenu bazéms. Siame lygmenyje } \\
\text { svarbu tinkamai nustatyti duomenis ir kataloguoti juos, t. y. sukurti veiklos } \\
\text { išteklių metaduomenu taikomaji modeli }\end{array}$} & \\
\hline & \\
\hline \multirow{2}{*}{$\begin{array}{l}\text { Informacijos radimui, ryšiams ir migracijai (Molholm, 2006) } \\
\text { Metaduomenys tampa naudinga priemone ieškant informacijos, ją naudojant } \\
\text { ir išsaugant turini. Esant daugialypei veiklos terpei ir jvairiatipems } \\
\text { technologijoms, jie gali padèti suformuoti lengva ir patogia duomenù } \\
\text { naršymo struktūra, palaikyti ryšius bei užtikrinti informacijos migracija tarp } \\
\text { skirtingu vidaus I išorés funkcinés veiklos sričiu skaitmeniniu sistemu, } \\
\text { platformu ar jmonių }\end{array}$} & 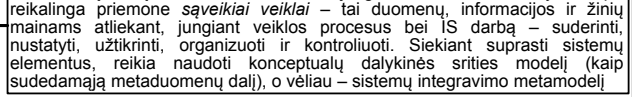 \\
\hline & \\
\hline \multirow{2}{*}{\begin{tabular}{|l|} 
Duomenu neprieštaringumui palaikyti \\
(Giovinazzo, 2009; Acadyлnaes, 2009) \\
Metaduomenys lemia duomenu neprieštaringuma, nes, pvz., skirtingose \\
sistemose vartojami skirtingi skaičiu, datu ir laiko formatai; tie patys veiklos \\
rodikliai skirtingose šalyse skaičiuojami skirtingai arba ta pati produkcija \\
matuojama skirtingais matavimo vienetais ir pan. Viena pasekmiu - aktualių \\
duomenų, ataskaitų neatitiktis
\end{tabular}} & $\begin{array}{l}\text { budas mod } \\
\text { sprendimus } \\
\text { ¿monių veik }\end{array}$ \\
\hline & \\
\hline \multirow[t]{2}{*}{$\begin{array}{l}\text { Užtikrinti integracijos / infrastruktūros stabiluma } \\
\text { (3aвьялова, 2011) } \\
\text { Stabili veiklos informacijos integracijos infrastruktūra galima tuomet, kai } \\
\text { grindžiama metaduomenu valdymo procesais, užtikrinančiais teikiamos } \\
\text { informacijos patikimuma, leidžiančiais geriau suprasti visus įmonès veiklos } \\
\text { duomenis, juos veikiančius veiksnius ir kaitą }\end{array}$} & $\begin{array}{l}\text { Ivalros me } \\
\text { semantinis } \\
\text { veiklos pro } \\
\text { išorinių) a } \\
\text { katalogai le } \\
\text { galimybę tik }\end{array}$ \\
\hline & \\
\hline $\begin{array}{l}\text { Duomenu vientisumui palaikyti ir mažinti informacijos } \\
\text { valdymo išlaidas (Miniotaité ir Zalieckaité, 2011) } \\
\text { Metaduomenu objektu valdymas arba bendros platformos ir semantinio } \\
\text { lygmens palaikymas - svarbus informacijos valdymo veiksnys, grindžiamas } \\
\text { bendra duomenu saugykla. Tai leidžia palaikyti veiklos logikos vientisumą, } \\
\text { mažinti palaikomų objektų skaičių bei duomenų saugojimo išlaidas }\end{array}$ & \begin{tabular}{l|} 
u su \\
nybè \\
rinio \\
mus, \\
eikia
\end{tabular} \\
\hline \multirow{2}{*}{\begin{tabular}{|l|} 
Objektyviai interpretuoti ir doroti informacija (Ланин et al., 2012) \\
Dokumentu duomenis susiejus su metaduomenimis, randasi galimybè \\
interpretuoti ir doroti juose saugoma informacija, t. y. jtraukti j dokumentus \\
informaciją, atskleidžiančią ju struktūrą ir semantiką (duomenu prasmę). \\
Šios specialios aprašomosios žymęs (metaduomenys) leidžia susieti \\
dokumentus ir konkrečius ju fragmentus su dalykinés srities ontologija, o \\
véliau - naudoti informacijos ieškai, dokumentų kūrimui ir pan. \\
\end{tabular}} & \begin{tabular}{l|} 
nenu \\
netų \\
aket
\end{tabular} \\
\hline & \\
\hline \multirow{2}{*}{\begin{tabular}{|l|} 
Išvengti veiklos funkciju dvigubinimo, duomenu pertekliaus \\
(Pant, 2009a; Pant, 2009b; KлnMOB, 2011) \\
Veiklos funkciju gausa, kuria siūlo IS, reikalauja tam tikro struktūravimo ir \\
sutvarkymo, nes kitaip būtu sunku išvengti funkciju dvigubinimo. Problema \\
sprendžiama centralizuota metaduomeny saugykla, kuri leidžia saugoti \\
vykdomy veiklu ir funkciju aprašymus, ju semantika (bet ne realizaciją), \\
priklausomybes eksploatuojamoms IS bei standartizuoti metaduomenis
\end{tabular}} & $\begin{array}{l}\text { kirstytu IS priežiūros technologijos reikalauja i itraukti } \\
\text { eksploatuojamu duomenu baziu struktūra (t. y. aprašyti } \\
\text { teklius metaduomenu lentelèse). Metaduomenys padeda } \\
\text { je lenteles / esybes ir lengviau palaikyti skirtingu sistemu }\end{array}$ \\
\hline & \\
\hline \multirow{2}{*}{\begin{tabular}{|l|} 
Aprašyti programu sistemos aspektus (Лядова, 2008) \\
Metaduomenu pagalba aprašomi ivairūs aspektai: taikomosios srities \\
objektai ir IS objektai, funkcijos, dokumentai ir IS ataskaitos, veiklos procesai \\
ir dokumentu judèjimas, naudotojų sąsaja, vaidmenų apsauga ir kt.
\end{tabular}} & \\
\hline & \\
\hline \multirow{3}{*}{$\begin{array}{l}\text { Užtikrinti sklandžius ir efektyvius veiklos procesus, palaikyti } \\
\text { geresnj bendra supratima (Schmidt ir Otto, 2008) } \\
\text { Sklandu veiklos procesu vykdymą gali užtikrinti metaduomenys, kurie aprašo } \\
\text { veiklos objektu duomenu struktūras (t. y. ju atributus ir saryšius) ir teikia } \\
\text { informaciją, kaip tiksliai veiklos procesuose panaudoti veiklos objektus. } \\
\text { Aukšta metaduomenu kokybè (t. y. naujinami, tikslūs ir išsamūs) padeda } \\
\text { kurti ir palaikyti bendrą supratimą apie veiklos objektus ir veiklos procesus }\end{array}$} & $\begin{array}{l}\text { institucijomis bei vidaus ataskaitos ir plan } \\
\text { aiškiai ir suprantamai nusakytu veiklos }\end{array}$ \\
\hline & $\begin{array}{l}\text { tiek standartizuoti vidaus } \\
\text { turi lanksčiai prisitaikyti }\end{array}$ \\
\hline & \\
\hline \multirow{2}{*}{\begin{tabular}{|l|} 
Sukurti ir suvokti informacini veiklos konteksta \\
(Kilpeläinen ir Nurminen, 2007) \\
Metaduomenu lygmuo, panaudotas imonès veiklos ir informacijos \\
architektūros modelyje, išplečia informacijos valdymo ir integracijost \\
galimybes: padeda sukurti informacini veiklos kontekstą, sujungti \\
informacinius konceptus su atitinkamais veiklos padaliniais ir darbo \\
vaidmenimis
\end{tabular}} & $\begin{array}{l}\text { nacijos sraut } \\
\text { enų kokybei }\end{array}$ \\
\hline & \\
\hline \multirow{2}{*}{$\begin{array}{l}\text { Mažinti semantinio integravimo spragas (Stary et al., 2010) } \\
\text { Integruojamụ duomenu procesu srautas turi būti struktūriškai ir semantiškai } \\
\text { tikslus bei suderintas darbo užduočiu lygmenyje ir sintaksiškai teisingas } \\
\text { technologiju lygmenyje (dorojant specifikacijas). Specifikacija yra veiksminga } \\
\text { tuomet, kai turi detalius dalykinès srities elementus, t. y. metaduomenų } \\
\text { struktüros aprašymą }\end{array}$} & $\begin{array}{l}\text { xdant } \\
\text { s tam } \\
\text { acija, }\end{array}$ \\
\hline & $\begin{array}{l}\text { al., 2012) } \\
\text { valdymu. }\end{array}$ \\
\hline \begin{tabular}{|l|} 
Švelninti žiniu prieštaravimus (Candan et al., 2008) \\
Žinios, integracijos metu igytos iš skirtingu duomenu šaltiniụ, dažnai \\
prieštarauja. Problema reikalauja integracija paremti metaduomenis is in \\
nuolatiniu eksperto grižtamuoju ryšiu, padedančiu pastebèti ir spręsti \\
konfliktus tarp integruojamų skirtingu šaltinių
\end{tabular} & $\begin{array}{l}\text { duomenu modelis yra svarbus igyvendinant duo } \\
\text { s sprendimų palaikymo priemonę): teikia duo } \\
\text { limo taisykles bei duomenu kelionès informaciją } \\
\text { imo reikalingumą ir leidžia išvengti nereikalin } \\
\text { ina pradinių duomenų kokybę }\end{array}$ \\
\hline
\end{tabular}


Remiantis moksliniais požiūriais (3 pav.) ir kitais tyrimais (Blue et al., 2011; Inmon et al., 2008; Kilpeläinen ir Nurminen, 2007; Pant, 2009a) teigtina, kad įmonès, naudojančios MD saugyklą, turi žinių šaltinị (veiklos vienetų, duomenų struktūrų, objektų schemų, darbuotojų jžzvalgų), kuris leidžia spręsti integravimo uždavinius. Tyrimai atskleidžia, kad kuo greičiau i̇monè renka ir naudoja tinkamą informaciją, tuo labiau mažina išlaidas (Burton et al., 2006), igyja, didina ar skatina finansinį, operacinị pranašumą (Jurkowski ir Slowinski, 2007). Svarbiausia tai, kad valdomi MD gali padeti:

- užfiksuoti ir integruoti duomenų turini (Nagy ir Tolea, 2011), sukurti ir naudoti struktūruotą informacinį veiklos turinị (Kilpeläinen ir Nurminen, 2007);

- apibrèžti duomenis integracijos lygmenyje ir užklausas, skirtas rasti individualius konceptus (Berthold et al., 2010);

- sekti / kontroliuoti duomenu kaita ir integruoti duomenis iš daugybès fizinių irrenginių (Mhashilkar ir Sarkar, 2009; Лядова, 2009);

- sieti skirtingų šaltinių duomenis (Hristov, 2012) ir siekti susietumo tarp veiklos ir IS modelių (Лядова, 2008);

- kurti sklandžius duomenų tiekimo procesus ir gerinti duomenų kokybę (Shankaranarayanan et al., 2006);

- $\quad$ igyti išskirtini integracini pranašumą (Jurkowski ir Slowinski, 2007).

MD igyvendinimas (Mhashilkar ir Sarkar, 2009) - esminis sẻkmingos duomenu integracijos realizacijos komponentas. Taigi, imonėms reikia tokių IS, kurios rinktu ir valdytų tinkamo turinio informaciją, padètų suprasti ir pasiekti įrašus kartotinai, patvirtintų autentiškumą, tikrumą, vientisumą, naudojamumą ir įrodytų ịrašų kokybę (ISO, 2009).

Nors buvo pateiktos įvarios MD naudos įžvalgos (3 pav.) ir tai, kad atsirado supratimas, jog reikia centralizuoto (arba išskirstyto, mišraus) duomenų ir jų MD tvarkymo / naudojimo, lieka didelis atotrūkis tarp galinčių taikyti savo kasdienèje informacinèje veikloje MD teikiamą naudą ir realiai ją naudojančių, tinkamai formuojančių MD lygmenį, nes i̇monès neskiria tam reikiamų priemonių ir išteklių (Асадуллаев, 2009). Ве to, sunku surinkti MD reikalavimus, didelès išlaidos mokymui ir reikiamai įrangai, o blogiausia - imonés negeba ir nežino, kaip nustatyti MD vertę, ịvertinti naudą ir pagristi investicijas (Shankaranarayanan et al., 2006). Informacijos integracija (apimanti duomenų, MD valdymo operacijas) verčia plačiai ir visapusiškai suprasti duomenų šaltinių semantiką, jų unikalius MD (aprašymo schemas). Be to, toliau lieka iš esmès rankinis, brangus ir daug laiko užimantis procesas (Göres ir Dessloch, 2007). Dažnas atvejis, kai integracijai reikia duomenų, kurie iš viso nẻra užfiksuoti; sunku suprasti semantinius ryšius tarp šaltinių ir jų informaciją perteikiančių sistemų (Halevy et al., 2005). Faktas, kad įmonėse gausu naudojamų duomenų elementų, kurie nesaugomi ilgalaikèse DB (pvz., tarpiniai skaičiavimai, agregacijos), bet turi MD savybes (pvz., dydị, duomenų tipą, ryši su tam tikra veiklos sritimi) (Loshin, 2012). Tikrovèje trūksta integruoto valdymo požiūrio ir formų: normalizuotų objektyvių operacinių duomenų saugojimo, bendro visų atributų šaltinių naudojimo, išvalytų ir profiliuotų, aiškios kilmės ir struktūros duomenų (Wik, 2011). Nesklandumų priežastis - nèra aprūpinimo MD, bendro supratimo apie ị veiklą nukreiptus MD tarp organizacinių darbuotojų su skirtingais vaidmenimis (Verbitskiy et al., 2009). Todèl, imonių specialistai, kurie 
vykdo informacinius projektus, susiduria su duomenų kokybès ir MD (kaip įrodančios informacijos) naudojimo problema, kuri turi neigiamą ịtaką veiklai (Bologa ir Bologa, 2011).

Darytina prielaida, kad informacinių išteklių (objektų) integracija turi kisti pereiti nuo tradiciškai susiklosčiusios situacijos (sintaksinès turinio konsolidacijos duomenų interpretacijos, kuri neteikia duomenims prasmès) prie prasminio (semantinio) integracijos požiūrio (arba duomenų ir jų turinio jungimo, duomenų saugojimo kartu su MD), kuris leistų efektyviau naudoti taikomuosius duomenis, suteiktų reikiamą funkcionalumą i̇monių IS (Хитрова, 2010). O prieštaringos integracijos problemos, pvz., minèta duomenų kokybès (naujumo, patikimumo), priklausanti nuo duomenu šaltiniu kokybès, gali būti sprendžiama naudojant MD grįstas integracijos technikas (Dong ir Naumann, 2009; Mhashilkar ir Sarkar, 2009; Wik, 2011).

Apibendrinant pasakytina, kad bendro MD modelio, kontroliuojamų duomenu žodynų, valdančių skirtingus schemų komponentus, bei MD schemų (ISO, 2009) įrankio, kuris palaiko tarpveiksmingumą ir užtikrina ilgalaikị įrašų naudojimą; valdo ịrašus, nustatydamas būdą, kaip įrašai turi būti struktūruojami ir teikiami - naudojimas yra pripažǐstamas kaip centralizuotas požiūris sieti ir valdyti ịvairių įmonès padalinių informacijos mainus (Hert, 2004). Pritartina įžvalgoms, kad jei naudojama daug sudėtingų IS, dažnai keičiasi darbuotojai (Inmon et al., 2008) ir vis daugiau informacijos atsiranda, išlieka ir tampa skaitmeninè, tai MD kūrimas ir naudojimas turi realiai tapti neatsiejama informacijos kūrimo, organizavimo ir sklaidos procesu dalimi (Qin ir Prado, 2006). Taigi, duomenų integracija turi remtis MD (arba veiklos modelių valdymu, integravimu bei jų perteikiamais MD) grindžiama infrastruktūra, siekiant: integruoti duomenų salas (Nagy ir Tolea, 2011), surinkti vertingus duomenis ir turèti bendrą prieigą prie daugialypių duomenų šaltinių (Wik, 2011), mažinti duomenų praradimo riziką (Замятина et al., 2008), užtikrinti ir valdyti duomenų kokybę (Verbitskiy ir Yeoh, 2011). MD reikia duomenų integravimui, nes be MD informacijos ne tik neįmanoma turèti patikimai sinchronizuotos prieigos prie duomenų, greitai suvokti informacijos, bet ir suprojektuoti duomenų integracijos, duomenų migravimo (pasikeitimo).

\section{Informacijos integracijos architektūros aspektai metaduomenų požiūriu}

Dabar diduma įmonių turi pritaikyti IS savo realioms reikmėms, bet tyrimai rodo, kad nèra gerų, greitai ị veiklos ir duomenų valdymo kaitą reaguojančių, leidžiančių efektyviai tvarkyti atliekamus veiklos procesus ir funkcijas, visą IS aplinką, architektūrų (Ong et al., 2011). Duomenų integracijos sistemos susiduria su daug ir autonomiškais šaltiniais, sudètingais dorojimo procesais, neatsiejamais nuo veiklos semantikos (Marotta et al., 2010). Nepaisant to, integracijos architektūra turi leisti rinkti duomenis iš ịvairių šaltinių, kad aprūpintų formuojamas ataskaitas, turimas IS būtina informacija bei telktis ị teisingą, tinkamos formos informaciją (pvz., tam parengti santykinai pastovų MD žinyną) (Bologa ir Bologa, 2011). Deja, taikliai pažymima (Pant, 
2009b), esminè informacijos valdymo architektūrų problema - néra lankstaus MD valdymo. Pvz., mokslininkai (Ong et al., 2011), tyrę penkių lygių - tai duomenų šaltinių, ETL procesų (išgavimo, transformavimo, ikèlimo), duomenų saugyklos, naudotojo ir MD - architektūrą teigia, kad geros architektūros modelio sąlyga - MD lygmuo. Kiti tyrejai (Baars ir Kemper, 2008; Лядова, 2008) mano panašiai: informacijos valdymo infrastruktūroje svarbus vaidmuo turi tekti nestruktūruotų duomenų integracijai. Todèl pagrindiniai lygiai - duomenu, logikos ir ieškos - turi remtis MD: duomenų, MD ir dokumentų dorojimas, operacinių duomenų skaitmeninio turinio kaupimas; surinktų duomenų struktūruoto ir nestruktūruoto turinio analizè, aiškinimas, veiklos rezultatų ir aktualių žinių sklaida; informacijos teikimas (naudojimas, užklausų ieška) (4 pav.).

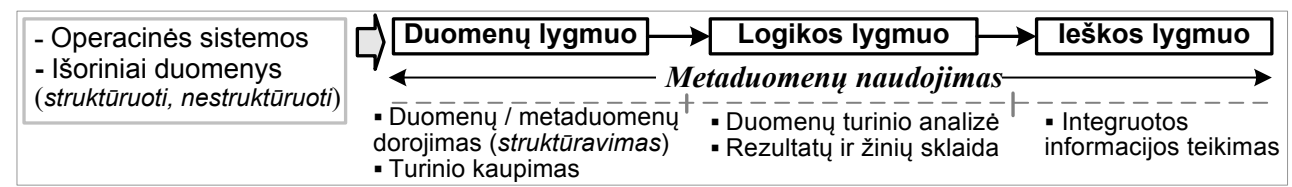

4 pav. Integruoto informacijos valdymo infrastruktūros lygiai (sudaryta autorès)

Veiklos informacijos integravimo tikslas - jungti ị visumą išsklaidytus ir įvairiarūšius duomenų šaltinius, gerinti ir naujinti informacinių procesų valdymo būdus. Siekiant valdyti šią îvairovę, reikia integravimo plano, kad šaltiniuose rastus duomenis būtų galima paversti ị duomenų modelị, objektų schemų struktūras ir tinkamą darnų formatą (Göres ir Dessloch, 2007). Kad integravimo procesas vyktų, reikia apibrèžti duomenų šaltinių (pvz., DB, el. dokumentų rinkmenų) ir duomenų tikslų (pvz., duomenų užklausų, integravimo schemų) rinkinius, organizuoti transformacijos procesą (Marotta et al., 2010). Ši ryši apibendrinsime išraiška:

\section{Duomenų šaltiniai $=>$ Duomenų tikslai $=>$ Duomenų transformacijos procesas}

Integravimui taikytinas ne tik reliacinis modelis, bet ir kiti būdai: centralizuota duomenu saugykla (nukreipta ị konkrečią sritị, bet nekintančius duomenis); tarpininko architektūra (dorojimo lygmuo, skirtas duomenų perkèlimui ir integravimui, filtravimui, MD tvarkymui); paskirstytos (federacines) DB (loginis, o ne fizinis duomenu jungimas ir bendra sąsaja prie atskirų DB, bet sudètingos architektūros) (Marotta et al., 2010). Bet nesvarbu, kokia yra taikoma integravimo architektūra, naudotojai sistemas vertina jiems teikiamos informacijos kokybe (turiniu) ir tuo pat metu turimų IS, jų komponenčių, posistemių reikalingumą.

Tyrimai teigia, kad reikia efektyviau struktūruoti, integruoti ir valdyti gausų duomenų srautą naudojant MD bazę (išteklių saugyklą) kaip integruoto veiklos valdymo ir plètojimo įrankị. Bet tyrimai pagrindè, jog šiuo metu duomenys silpnai integruojami. Tik naudojant $M D$ modeli, grịstą dalykinès srities MD analize, ir integruojant duomenis ị saugyklą su MD, kurie leistų spręsti integravimo problemas (Rahman et al., 2012), bei MD saugyklą, kuri kauptų, valdytų ir dalintųsi įmonès darbo reikmèms atrinktais, suderintais duomenų (išteklių) MD (Blue et al., 2011), galima sukurti patikimą veiklos valdymo ir informacijos dorojimo sistemą. 
Suprastintai duomenų integravimo valdymo procesą galima skirstyti ị keturis lygius (5 pav.): duomenų, MD (arba individualų, aprašomosios informacijos), saugojimo ir duomenų naudotojo.

\begin{tabular}{|c|c|c|c|}
\hline \begin{tabular}{|c|} 
1. Veiklos \\
duomenų lygmuo
\end{tabular} & $\begin{array}{c}\text { 2. Modeliai / metaduomenụ } \\
\text { lygmuo }\end{array}$ & $\begin{array}{c}\text { 3. Duomenų } \\
\text { saugojimo lygmuo }\end{array}$ & $\begin{array}{l}\text { 4. Naudotojo } \\
\text { aplinkos lygmuo }\end{array}$ \\
\hline $\begin{array}{l}\text { 1. Duomenys yra } \\
\text { kuriami arba gaunami } \\
\text { specializuotais ịrankiais, } \\
\text { rankiniu būdu ar iš } \\
\text { atsiųsto turinio }\end{array}$ & $\begin{array}{l}\text { 2. Isigilinti ji informacinius srautus (turimas DB) } \\
\text { ir jų technologijas, nustatyti duomenu } \\
\text { elementus ir ju savybiu semantiką ir kaip } \\
\text { duomenys yra susieti su procesais, } \\
\text { paslaugomis (t. y. atlikti reikalavimu duomenu } \\
\text { analize, kuri leistu nustatyti duomenis (ar ju } \\
\text { dali) kartu su juos identifikuojančia informacija, } \\
\text { ju saugojimo ar buvimo vietą) }\end{array}$ & $\begin{array}{l}\text { 3. Čia duomenys iš } \\
\text { veiklos duomenų lygmens } \\
\text { turi patekti naudojant } \\
\text { metaduomenų lygmenį }\end{array}$ & $\begin{array}{l}\text { 4. Teikti duomenis tinkamiausiu } \\
\text { būdu ir pageidaujamu formatu } \\
\text { bei remtis metaduomenimis, } \\
\text { kad duomenu naudojimas taptų } \\
\text { aiškus ir objektyvus, siekiant } \\
\text { informuotų veiklos sprendimų }\end{array}$ \\
\hline
\end{tabular}

5 pav. Informacijos integravimo valdymo lygiai (sudaryta autorès)

Tyrimai tvirtina, kad galima taikyti įvairius integravimo valdymo gerinimo būdus, atsižvelgiant $\mathfrak{i}$ tikslus, turimas priemones, autorių kvalifikaciją ar požiūrị, kitas aplinkybes (6 pav.).

Priemoné ar būdas (apibūdinimas)

$\rightarrow$ Suformuoti įmonès informacijos metaduomenų ontologini modeli (arba bendrajį informacijos modeli) $>$ Zhang et al., 2010

Kurti duomenų integravimo procesų modeliavimo metodologijq naudojant veiklos modeliavimo kalbas (a), pvz., aprašyti dinaminèmis valdomų procesų / sekų diagramomis (b) $>$ Kiauleikis ir Kiauleikis, 2005 (a); Kilpeläinen ir Nurminen, 2007 (b)

Sudaryti grafo tipo duomeny (ir su jais susijusių metaduomenų) ryšių modelius (ir vèliau transformuoti į reliacines, grįstas lentelèmis, DB) bei padaryti prieinamus metaduomenų artefaktus > Gores et al., 2009

Kurti ir naudoti veiklos ontologija (veiklos modeliu) gristus integruotus metaduomenis (kaip globalius), $\rightarrow$ igalinančius bendrai ir objektyviai valdyti duomenu sandèlio schemos apibrèžimą, kitu duomenu struktūru schemas, srities žinių šaltinius bei kitus metaduomenis $>$ Blue et al., 2011

Remtis j̇monés architektūros (veiklos ir IT) modeliu kaip integracijos planu, siekiant palaikyti informacijos struktūravimą: duomeny modelis nauju duomeny integracijai ir metaduomenys nestruktūruotiems dokumentams (informacijos ištekliams) skirtinguose sąryšių aspektuose Hinkelmann et al., 2010

Duomenų integravimą grįsti integracijos proceso dalyvių (srities ekspertų) turimomis aktyviomis žiniomis (arba grižtamuoju ryšiu), t. y. jas taikyti pasirenkant ir tikslinant duomenų integravimo užklausas, siekiant kuo aiškiau įvertinti integruojamų duomenų kokybę ir atitikimą tarp duomenų ar metaduomenų elementų (arba korektiškai integruoti) $>$ Yan et al., 2013

Integruojamus duomenu šaltinius ir kokybę jvertinti bei pagristi veiklos imitavimo modeliu, paremtu probleminès situacijos sprendimu, bei sudaryti kokybès (ciklini) grafą

$>$ Marotta et al., 2010

Kurti duomeny integravimo metamodelj, teikiantj galimybę probleminés srities duomenis formaliai aprašyti ir analizuoti skirtingais aspektais jivairiuose abstrakcijos lygiuose bei sujungti duomenų semantiką $\rightarrow$ (t. y. veiklos metaduomenis, i̇monès žinias). Metamodelis netechniniams naudotojams būtų reprezentatyvi schema, padėsianti suprasti informacijos gavimo šaltinius, giminingu duomenų ryšius, vykstančias duomenų transformacijas $>$ Nagy ir Tolea, 2011

Vizualizuoti duomenų ryšius, naudojant metaduomeny saugykla (kaip duomenų valdymo komponentą, $\rightarrow$ igalinanti rinkti duomeny srautą ir pateikti naudotojams duomenu ryšius per abstraktu (suburiantj informaciją) metaduomenų sluoksnį) $>$ Jain ir Thomson, 2013

Kurti ar naudoti tradicinius CASE (angl. Computer Aided Software) j̇rankius, palaikančius daugiasluoksnių $\rightarrow$ metaduomenų ir modelių (kaip glaudesnès integracijos - ne tik duomenų, bet ir naudojamų veiklos modelių) kūrimą, valdymą ir perdavimą iš vienos sistemos į kitą > Замятина et al., 2008; 2013

Taikyti matricinės struktūros universaliq DB, integruojančią jvairių reliacinių DB struktūras ir turinj

Микляев, 2010; 2013

Duomenims pasiekti ir sujungti naudoti SQL užklausas, paremtas duomenų šaltinių metaduomenimis, o rezultatus transformuoti tarpiniais agentais. Tačiau iš anksto reikia suderinti su šaltinio tiekejju duomenu schemos struktūrą; metaduomenyse nurodyti, kokius kintamuosius šaltinis suteiks užklausai bei kitus reikiamus parametrus agentui, t. y. suformuoti užklausą $>$ Поляков et al., 2013

Pasitelkti žinių bazę, kaip lankstu požiūri j integravimą, t. y. tarpinj sluoksnį tarp informacijos šaltinių (DB su metaduomenimis) ir naudotojų informacijos. Žinių baze, panaudota kaip sąsaja skirtingų šaltinių uždaviniams spręsti, naikina naudotojų reikmę ieškoti relevantinių duomenų šaltinių, atskirai su jais dirbti ir pan.

$>$ Егошина ir Вороной, 2011

6 pav. Integravimo valdymo gerinimo priemonès, nukreiptos ị metaduomenų poveikị 
MD valdymo struktūra turi jungti ir standartizuoti veiklos informacijos $\mathrm{MD}$, o pastarieji - leisti patogiai integruoti immonès informaciją, palaikyti IS sąveikumą ir galiausiai realizuoti žinių bendrinimą. Todèl tyrẻjai (Zhang et al., 2010) siūlo kurti i̇monès informacijos MD ontologinį modelị, kuris išreikštų ir aprašytų veiklos sritị, nurodytų kaip rinkti informaciją, atskleistų būtinus jos elementus, ryšius, gavimo ir teikimo ypatumus bei atsižvelgtų i informacinius, turinio ribojimus (7 pav.).

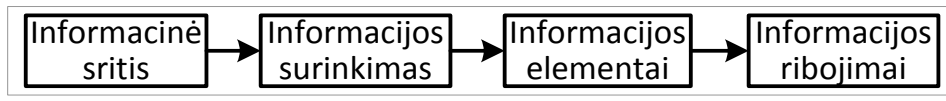

7 pav. Bendrasis metaduomenų struktūros elementų modelis (sudaryta autorès, remiantis Zhang et al., 2010 tyrimu)

Imonès veiklos procesu apibūdinimas ir modeliavimas padeda ịvertinti esamą būklę, pastebèti ir nustatyti integravimo uždavinius. Tyrèjų (Kiauleikis ir Kiauleikis, 2005) vertinimu, informacijos kokybès parametras - modeliavimo tikslo funkcija, kuri leidžia ịvertinti sistemą naudotojo požiūriu. Todèl integravimo procesai negali būti analizuojami atsietai nuo informacijos šaltinių modelių. Pasak (Jain ir Thomson, 2013), esamo duomenų srauto ir duomenų kilmès ryšių pateikimas schema - būdas atskleisti duomenų radimąsi, jų kelią iki paskirties vietos ir nuolat teikti informaciją apie duomenis. Kaip konstatuoja (Kilpeläinen ir Nurminen, 2007), veiklos procesu modeliai (darbų sekų diagramos), sudaryti atlikus veiklos analizę, gali virsti objektyviu MD lygmeniu - tai nuosekliai ir lygiagrečiai komunikuojančios veiklos, kurios atskleidžia: veiklos srautų sudèti (struktūrą) ir jų ryši su veiklos funkcijomis, ryšius tarp procesų srautų ir dalyvių, duomenų šaltinius ir sistemai keliamas reikmes (ribojimus), paaiškina faktinị DB (duomenų) turinị. Pagal (Halevy et al., 2005; Kilpeläinen ir Nurminen, 2007; Kilpeläinen, 2007), naudojant ịprastinį veiklos, duomenų modeliavimą, galima nustatyti (atnaujinti) aktualią veiklai informaciją ir apibrèžti informacijos dorojimo modelị, o šis - leistų suprasti ir kritiškai vertinti, kokią informaciją įmonè turi, kokios reikia ar kokia jos semantika, ryšiai tarp imonės informacinių konceptų, ką informacija iš tikrųjų reiškia veiklos fone, t. y. užpildyti MD lygmenį (valdyti reikalavimus, reflektuoti veiklos poreikių turinį).

Nustatyta (Göres ir Dessloch, 2007; Göres et al., 2009), kad integracijos sistemos kūrimas ịtraukia daug užduočių, kurioms atlikti reikia MD artefaktų: integravimo schemos yra projektuojamos nuo pat pradžios arba jungiamos pradinès schemos. Integracijos ekspertai ir programinès ịrangos inžinieriai turi numatyti ịvairių rūšių MD, kurių reikia šioms užduotims, valdymo sąsajas: DB schemos dažnai kuriamos naudojant konceptualius metamodelius (pvz., E/R - esybių ryšių) ir tik vèliau kuriamos fizinès schemos, kurios pateikiamos duomenų aprašymo kalba (pvz., SQL, XML). Struktūra ir dinaminiai taikomosios ịrangos programų (IS) aspektai gali būti konstruojami UML dalykinès srities kalba.

Integracija siejama ir su penkių lygmenų seka (8 pav.). Tik jungiant šias skirtingas integracijos dimensijas kartu, galima plètoti integruotą požiūrį. Bet tyrime (Brun et al., 2009) pažymima, kad visi lygmenys vis dar neįvertina realių veiklų ir problemų, veikia nekokybiškai ir jų veikla netenkina galutinių naudotojų. Blogai tai, jog nors įmonès 
ir sutaria, kad MD išteklių vienodinimas (pvz., grịstas standartais, terminų sąrašais, veiklos žodynais, temų žemèlapiais, katalogais), kaupimas ir tvarkymas yra būtinas, bet informacijos ieška, taikant nuoseklius MD, lieka didžiausia problema ir iššǔkiu.

\begin{tabular}{|c|c|c|c|c|}
\hline \begin{tabular}{|c|} 
1. Tikslus \\
dokumentavimas
\end{tabular} & 2.Skaidrumas & 3.Prieinamumas & $\begin{array}{l}\text { 4.Informacijos integracija } \\
\text { (bendri metaduomenys) }\end{array}$ & $\begin{array}{c}\text { 5. Automatinis } \\
\text { metaduomenų kūrimas }\end{array}$ \\
\hline $\begin{array}{l}\text { 1. Visos praktikos } \\
\text { situacijos ir žinios, net } \\
\text { glūdinčios darbuotojù } \\
\text { galvose (neišreikštos), } \\
\text { turi igauti formą ir būti } \\
\text { dokumentuotos, } \\
\text { struktūruotos bei } \\
\text { organizuotos }\end{array}$ & $\begin{array}{l}\text { 2. Veiklos informacija ir } \\
\text { dokumentai turi būti } \\
\text { aiškūs, visiems supran- } \\
\text { tami bei saugomi } \\
\text { centralizuotai (pvz., failu } \\
\text { serveryje, intraneto } \\
\text { puslapyje, informacijos } \\
\text { kataloguose, žinynuose) }\end{array}$ & $\begin{array}{l}\text { 3. Informacija turi būti } \\
\text { lengvai (tiesiogiai) } \\
\text { pasiekiama ir } \\
\text { randama ( } p v z \text {., } \\
\text { imonés intraneto / } \\
\text { ekstraneto serveryje) }\end{array}$ & $\begin{array}{l}\text { 4. Skirtinguose šaltiniuose (pvz., } \\
D B, \text { registruose, el. pašte, } \\
\text { dokumentu valdymo sistemose } \\
\text { ar intranete) išskirstytos } \\
\text { informacijos integracija } \\
\text { reikalauja apibrèžti bendrą } \\
\text { duomenų modeli arba bendrus } \\
\text { metaduomenis }\end{array}$ & $\begin{array}{l}\text { 5. Kurti metaduomenis } \\
\text { rankiniu būdu yra sudètinga, } \\
\text { o diduma turimų IS taip pat } \\
\text { nesékmingai tai atlieka. } \\
\text { Todėl reikalingi sprendimai, } \\
\text { leidžiantys automatiškai } \\
\text { importuoti duomenis, } \\
\text { užpildant bent dali } \\
\text { metaduomenų laukų }\end{array}$ \\
\hline
\end{tabular}

8 pav. Integracijos dimensijos lygiai (sudaryta autorès, remiantis Brun et al., 2009 tyrimu)

Siekiant bendros ir aiškios įmonès informacijos, reikia dviejų infrastruktūros komponentų (Jiang, 2012): duomenu saugyklos (integruotos DB) - jungti dalykiškai orientuotus operacinius duomenis, generuojamus iš ịvairių šaltinių, ir leisti pasiekti dabartinę ir istorinę informaciją; veiklos žodyno - užtikrinti bendrą įmonės veiklos ir informacinès veiklos terminiją. Pastarasis - aprašomųjų MD rinkinys, skirtas atpažinti ir apibūdinti duomenų išteklius, patenkančius ị saugyklą; gyvybiškai svarbus duomenų supratimui, naudotojų komunikavimui. Deja, remiantis (Loshin, 2012), daugumoje imonių tie patys terminai, vartojami įvairiose veiklos situacijose, turintys skirtingas reikšmes, bet vienodą prasmę, nèra oficialiai apibrěžiami ir dokumentuojami. Vadinasi, nesuderintos sąvokos, ypač esant gausiam nestruktūruoto ir išorés duomenų srautui (kaip didesnès sinonimų galimybès), turint daug sistemų, sunkina ir stabdo integravimą. Čia svarbus $M D$ procesas - veiksmai, susiję su veiklos dokumentų, taikomụjų paketų (DB ir programos kodo) apžvalga bei įmonés personalo atstovų apklausa, siekiant apibrèžti ir sukaupti bendras veiklos sąvokas.

Išaiškejjo, kad integravimas nèra lengvas uždavinys (1 pav.). Kita vertus, yra priemonès / dorojimo įrankiai (6 pav.), kurie pagerintų šị procesą. Beje, rinktis tokius (ar derinị), kurie labiausiai tiktų integraciniams poreikiams, turimai kvalifikacijai.

\section{Praktinis integracinès aplinkos tyrimas: ŽI veiklos valdymo atvejis}

Žmogiškųjų išteklių (ŽI) duomenų aibès laikui bègant sudètingėja, o duomenų iš skirtingų veiklos sričių integravimas tampa būtinybe. İmonių informacinis aprūpinimas integruota ŽI apskaitos informacija svarbus veiklos analizei atlikti, bendriems sprendimams priimti. Pažymètina, kad ŽI veiklos procesų (ŽIVP) valdymo skyrius vykdo įvairias, bendro derinimo reikalaujančias, funkcijas: valdo (apskaito, skaičiuoja, sistemina, kaupia) darbuotojų informaciją, bendrauja su vidaus padaliniais ir išorès imonèmis (gauna užduotis, teikia ir renka informaciją), teikia duomenis, siūlymus vadovams (9 pav.). Taip pat - tai vienas pagrindinių žinių šaltinių įmoneje, t. y. tarpi- 
ninkas ir informacijos skleidejas, savo veikla turintis prisidèti prie veiklos stiprinimo. Ar taip yra iš tikrujų? ŽI informacinès veiklos reikmès nuolat kinta (t. y. sensta IS, kinta veiklos turinys ir forma, veiklą reglamentuojanti teisinè aplinka, atskaitomybè), todèl tenka nuolat sekti, tirti, prižiūrèti ir susieti ịvairias duomenų šaltinių (ir IS) aibes. Šiame kontekste, ịvairi ir nuolat turinti vykti integracija (pvz., skirtingų informacijos apie darbuotojus šaltinių, su išorès el. paslaugomis, veiklos valdymo IS, finansiniais ir išlaidų apskaitos duomenimis ar nauja veiklos praktika), siekiant vientisos ŽIVP valdymo veiklą palaikančios IS, igyja ypatingą reikšmę.

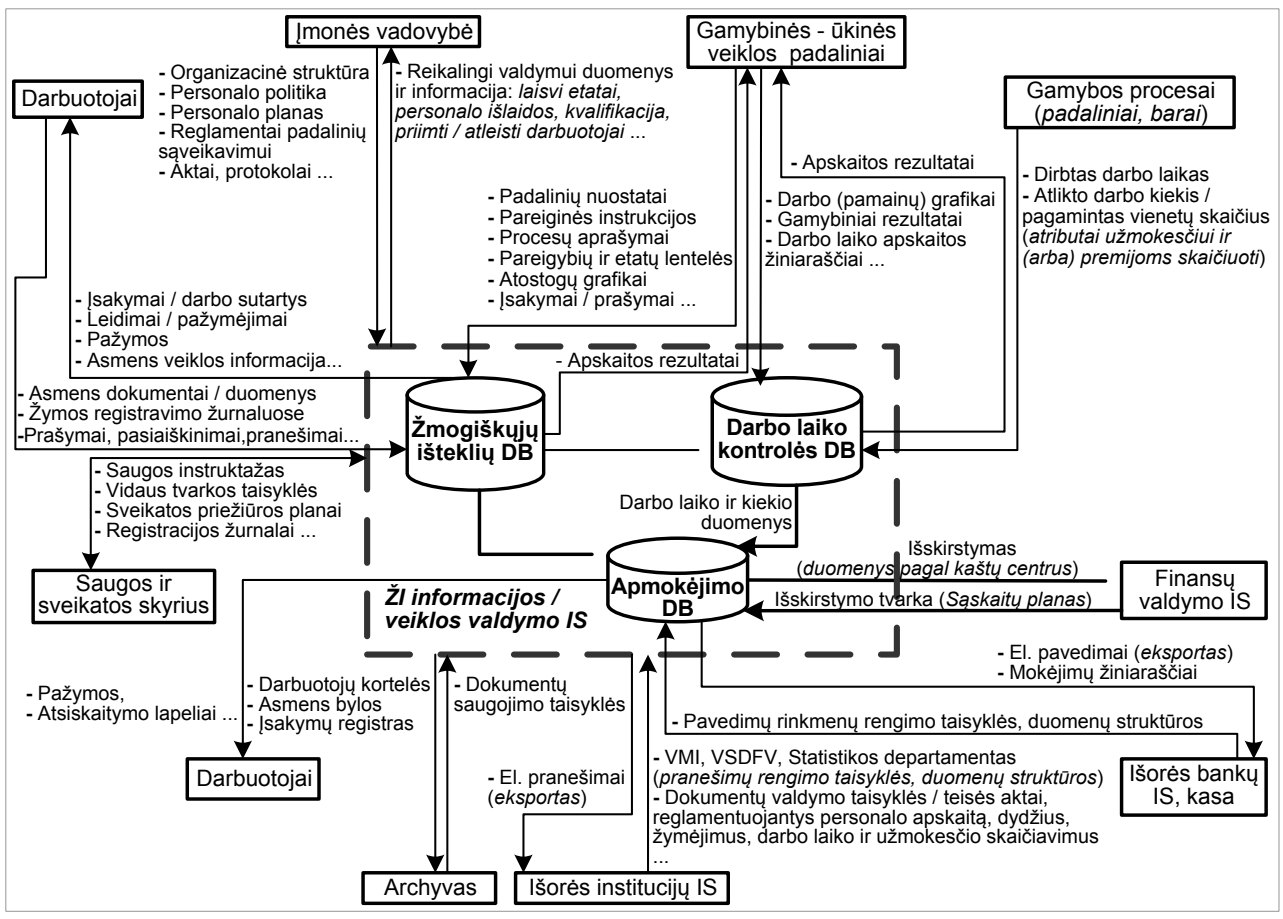

9 pav. ŽI veiklos komponentu, informacijos keitimosi ir valdymo schema (pramonès įmonès pavyzdžiu)

Nustatyta, kad komercinė ŽI apskaitos IS nèra gerai išplètota: trūksta ne tik informacinių darbo žodynų - žinynų, aktualios atributinès informacijos (MD komponentų), bet ir galimybès naudotojams sužinoti, kaip vykdyti informacinius procesus naujų (ir jau turimų) duomenų šaltinių integravimo procese. Todèl ŽI valdymo veiklai reikia intensyvios (išsamios, giluminès) stebėsenos ir žiūros, kad būtų konstruktyviai reaguota $\mathfrak{i}$ integracines problemas ir reikmes. Šią situaciją, kaip minèta, gali lengvinti veiklos įvykių, informacinių srautų detalizavimas ir šią informaciją lydintys MD. Taigi, tiriant ši integracijos procesą, reikia nustatyti sprendžiamus uždavinius (10 pav.), o vèliau - jų informacinị turinị ir reikmes (faktinius įeigos / išeigos duomenų srautus) (11 pav.), t. y. unikalų ŽIVP duomenų dorojimo / integravimo modelį, būdingą i̇monei. 


\begin{tabular}{|c|c|c|c|c|c|}
\hline & 1.Darbo sutarties sudarymas & Perkélimas i kitą padalini & $\Rightarrow$ & 1. Apskaitos žinynai & $\begin{array}{l}\text { Tabelio kodai } \\
\text { emijavimo reglame }\end{array}$ \\
\hline & 2.Darbo sąlygų keitimas & Perkèlimas i kitas pareigas & $\frac{v}{D a r}$ & 2. Darbo laiko (pamainu) & $\begin{array}{c}\text { remijavimo reglamentas } \\
\text { (taisyklès) }\end{array}$ \\
\hline & 3.Darbo sutarties nutraukimas & Darbo uzmokescio keltimas & laiko & $\mathrm{s}$ & Padienis darbo grafikas \\
\hline & 4.Nuobaudos / padékos & Pavadavimas. & $\mid$ & \begin{tabular}{|c|} 
3. Grafiko priskyrimas \\
darbuotojui (ar pamainai)
\end{tabular} & Suminis darbo grafikas \\
\hline & 5. Atostogu suteikimas & Kasmetinès atostogos & & 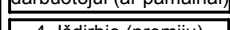 & \\
\hline struktūra & 6. Komandiruotés & MIKSIInes atostogos & D) & rezultaty pildymas & \\
\hline a) & 7. Darbuotojo kortelè & Karo prievolininkų ataskaita & & 5. Tabelio formavimas & Imonès parametrai \\
\hline & $\begin{array}{l}\text { 8.Ataskaitos / formos } \\
\text { institucijoms }\end{array}$ & \begin{tabular}{|l} 
VSDFV: 1-SD,2-SD,9-SD, \\
12-SD, 14-SD,
\end{tabular} & & 1ai & $\begin{array}{c}\text { Mokesčiu lentelès } \\
\text { Bankai }\end{array}$ \\
\hline & 9. Kitos ataskaitos & Pažymos darbuotojams & & $\begin{array}{l}\text { 2.Vienkartiniu/periodiniu } \\
\text { priskaitymy suvedimas }\end{array}$ & Priskaitymai / išskaitymai \\
\hline & 9. KItos ataskaitos & Analizès ataskaitos ... & & 3V/ienkartiniv/neriodinie & Sąskaitų planas \\
\hline & 10. Apskaitos žinynai & Padaliniu grupès & & išskaitymy suvedimas & Kiti klasifikatoriai \\
\hline & (sąrašai) & Padaliniai & $\begin{array}{l}\text { Atdygio } \\
\text { aldymo }\end{array}$ & & Atleidimai \\
\hline & 11. El. asmens bylos & Pareigu grupès & struktūra & 4.Tarpiniai skaičiavimai & Atostoginiai \\
\hline & formavimas & Pareigos & c) & & Nedarbingumai \\
\hline & & Etatai (pareigybės) & & sčio & $\begin{array}{l}\text { Avansai } \\
\end{array}$ \\
\hline & & Atleidimų priežastys & & skaičiavimas & Kiti skaičiavimai \\
\hline & & Darbo sutarčiu rūšys & & 6. Ataskaitu formavimas & $\begin{array}{l}\text { kirstymas (eksport } \\
\text { buhalterinę IS) }\end{array}$ \\
\hline & & Atostogų rūšys & & & Kasos žiniaraščiai \\
\hline & & Savivaldybès & & & $\overline{\text { vedimai }}$ \\
\hline & & Kiti klasifikatoriai & & & (eksportai i banku IS) \\
\hline & & & & & Atsiskaitymo lapeliai \\
\hline & & & & & Alimentų mokétojai \\
\hline & & & & nos & Kitos ataskaitos \\
\hline & & & & & $\begin{array}{l}\text { Statistikai: DUS-01, } \\
\text { LDV-02DA-01DA-05, }\end{array}$ \\
\hline & & & & & VVMI: FR0572, FR0573 ... \\
\hline & & & & & $\begin{array}{l}\text { VSDFV: } 10-S D, 13-S D, \\
S A M, N P-S D, \ldots\end{array}$ \\
\hline
\end{tabular}

10 pav. ŽIVP informacinio valdymo funkcinè struktūra: a) personalo, b) darbo laiko, c) atlygio

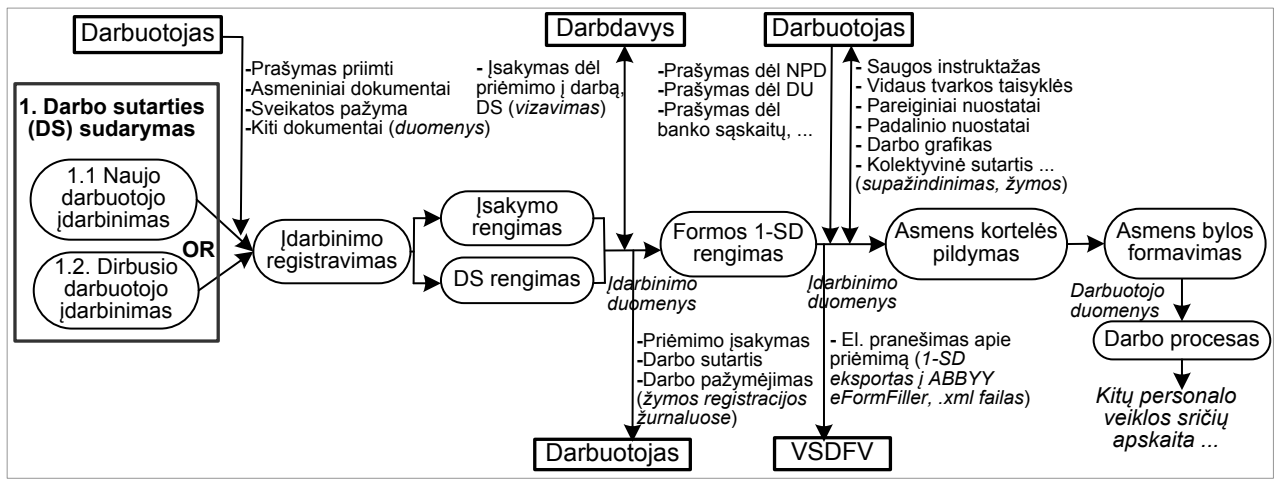

11 pav. ŽIVP valdymo funkcijos „Darbo sutarties sudarymas“ duomenų valdymo žingsnių logine struktūra ir tvarka

Viena vykstančių darbų seka aprašomas vienas funkcinès struktūros elementas (pvz., „Darbo sutarties sudarymas“, 11 pav.) ir jo veiklos. Šis pavyzdys vaizduoja ŽI veiklos funkcijos duomenų valdymo srautą (dokumentų, el. dokumentų ir pranešimų siuntimo, gavimo tvarką); duomenis, siunčiamus tarp vidaus proceso dalyvių ir išorès aplinkos (taikomųjų uždavinių, organizacijų). Šiuo atveju ŽIVP valdymo IS turi glaudžiai sietis (siųsti / gauti) su „Sodros“, išorès institucijos, IS - el. būdu pranešti, kad sudaryta darbo sutartis. T. y. reikia įdiegti bendrą ataskaitos formatą, užtikrinti reikiamą struktūrinių duomenų integravimą ir fiksuoti duomenu mainų $M D$ (prieigos adresus, e. deklaravimo formas, pildymo tvarką, turinị ir struktūrą, galiojimo datą, kt.). 
Siekiant atpažinti visus ŽIVP valdymui reikiamus duomenų išteklius, nustatyti ir ịvertinti turimos IS integravimo galimybes (pvz., importavimą, įrašymą, eksportavimą, sinchronizavimą), privalu tirti ir išreikšti modeliais visus veiklos modelio funkcinius vienetus, ju santykius („Darbo sąlygu keitimas“ ir t. t., 10 pav.).

ŽIVP informacinio valdymo atvejo analizè nebaigta, nes realus integravimas reikalauja nuodugnesnio tyrimo, todèl tyrimą tik apibendrinsime:

Integracinių sprendimų vykdymas nèra lengvas: reikia paruošti IT aplinką, naujas veiklos procedūras. Neretai išlaidos ŽIVP valdymo IS diegimui ar palaikymui planuojamos tada, kai IS nebeveikia ir būtinas naujinimas, pasikeitę teisès aktai, kt. İvairių IT ir veiklos sprendimų diegimas, integravimas į visą ŽIVP valdymo IS - tai atsakingas, kryptingas ir nuoseklus darbas;

Tik atskleidus esamus ŽIVP valdymo aspektus (reikalavimus), informacijos elementus ir jų tarpusavio ryšius $(9,10,11$ pav.), galima nustatyti integravimo uždavinių sudedamąsias dalis įmonès aspektu, parengti integravimo plètojimo galimybių planą ar ìdiegti integracijos technikas;

Integravimo modelio plètojimas - nenutrūkstamas, cikliškai kartojamas procesas, norint turèti nuoseklius ir vientisus ŽI veiklos procesus, aprèpiančius ne tik vidines IS, bet ir leidžiančius bendrauti su išorès programų IS; nuolat žinoti tikslią ŽI informacinių procesų erdvę, adaptyviai valdyti integravimo darbus bei IS vystymą, ìvertinant aplinkos kaitą, i̇monès interesus, t. y. vykdyti duomenų mainų ir integravimo nesèkmių prevenciją.

\section{Išvados}

Šiuo metu, kai įmonès negali išvengti ir išgyventi be duomenų integracijos, integracija turi kisti, tobulèti, t. y. pereiti nuo formalios integracijos (nurodančios tik šaltinius) prie prasminio integracijos požiūrio; rinktis integravimo valdymo priemones ir metodus, kurie leistų apibrěžti integravimo turinị. Būtent tokia forma, tinkanti šiandienos aplinkai (kai integracija sudetingejja ir tarpsta vis nauji integraciniai reikalavimai), yra veiklos MD formavimu grịstas (kontroliuojamas) integravimas.

Tyrimas parodè, kad MD - esminis duomenų kokybès gerinimo ir integracijos igyvendinimo komponentas; leidžia optimizuoti informacines paslaugas, priartinti jas prie realios veiklos reikmių. Bet tai nelengvas kelias: sunku surinkti taikomosios srities $\mathrm{MD}$ reikalavimus, nes $\mathrm{MD}$ dažnai yra saviti, skirtingai suvokiami ir reikia rinkti visos IS eksploatacijos metu. Be to, reikia gebèti visapusiškai suvokti duomenų semantiką ir apibrěžti schemas (unikalius MD), dirbti su ịvairiais įrankiais ir programomis. Nepaisant šiu ir kitu darbe minimu sunkumu, neišvengiamas faktas - integravimo procesu aprūpinimas MD (žiniomis), nes be MD informacijos neįmanoma suprojektuoti ir užtikrinti kokybiškos duomenų integracijos.

Tik išsamūs ir tinkamai konkretizuoti MD leidžia realiai pažinti ir veiksmingai kontroliuoti veiklos aplinkos duomenų srautus, mažinti duomenų (kokybės) praradimo riziką ir efektyviau spręsti integravimo metu kylančias problemas. Vadinasi, įmonèms būtina stabili, grindžiama MD valdymo procesais, integracijos infrastruktūra, 
kuri užtikrintų informacijos patikimumą, leistų kuo geriau suprasti veiklos duomenis, jų efektyvumą veikiančius veiksnius.

\section{Literatūra}

Agrawal, R., et al. 2008. The Claremont report on database research. ACM Sigmod Record. 37(3): 9-19.

Atkočiūnienė, Z. O.; Juškaitė, J. 2012. Žinių vadybos vaidmuo organizacijos strateginių kompetencijų plètojimui: atvejo tyrimas. Elektroninis mokymasis, informacija ir komunikacija: teorija ir praktika. 58-85.

Baars, H.; Kemper, H. G. 2008. Management Support with Structured and Unstructured Data - An Integrated Business Intelligence Framework. Information Systems Management. 25(2): 132-148.

Bara, A., et al. 2009. A model for Business Intelligence Systems Development. Informatica Economica. 13(4): 99-108.

Becker, J.; Knackstedt, R.; Serries T. 2003. Architectures for Enterprise Information Portals: An Approach to Integrate Data Warehousing and Content Management. The 11th European Conference on Information Systems, Naples, Italy, 10 p.

Berthold, H., et al. 2010. An Architecture for adhoc and collaborative Business Intelligence. The EDBT/ICDT Workshops, New York, USA, ACM, 6 p.

Blue, J.; Andoh-Baidoo, F.K.; Osatuyi, B. 2011. An Organizational Memory and Knowledge System (OMKS): Building Modern Decision Support Systems. Journal of Data Engineering. 2(2): 27-41.

Bologa, A. R.; Bologa, R. 2011. A Perspective on the Benefits of Data Virtualization Technology. Informatica Economica. 15(4): 110-118.

Brun, R., et al. 2009. Towards an Integrated Approach to Assess the Potential of an Enterprise to Mature Knowledge. WM2009, The 5th Conference of Professional Knowledge Management, p. 440-449.
Bučinskas, A.; Giedraitytè, V.; Raipa, A. 2013. Tinklaveika viešojo valdymo pokyčiu struktūroje. Regional Formation and Development Studies. 2(10): 46-56.

Burton, B., et al. 2006. Organizational Structure: Business Intelligence and Information Management. Gartner Research, 11 p.

Candan, K. S., et al. 2008. System support for exploration and expert feedback in resolving conflicts during integration of metadata. VLDB. 17(6): 1407-1444.

Carpinetti, L. 2003. Quality Management and Improvement: a Framework and a BusinessProcess Reference Model. Journal of Business Process Management. 9(4): 543-554.

Dassistil, M.; Panetto, H.; Tursi, A. 2006. Product-driven Enterprise Interoperability for manufacturing Systems Integration. The BPM 2006 Business Process Management Workshops, LNCS 4103: 249-260.

Dong, X. L.; Naumann, F. 2009. Data fusion resolving data conflicts for integration. PVLDB, 2(2): 1654-1658.

Duval, E., et al. 2002. Metadata Principles and Practicalities. D-lib Magazine. 8(4): 1-16.

Evangelou, C. E.; Karacapilidis, N. 2007. A Multidisciplinary Approach for Supporting Knowledge-Based Decision Making in Collaborative Settings. Journal on Artificial Intelligence Tools. 16 (6): 1069-1092.

Execution-MiH. 2013. Metadata Management definition - What is metadata? [interaktyvus]. [žiūrèta 2014-04-21]. <http://www. executionmih.com/metadata/definitionconcept.php>.

Farrokhi, V.; Pokoradi, L. 2013. Organizational and Technical Factors for Implementing Business Intelligence. Fascicle of Management and Technological Engineering. XXII (XII): 75-78.

Folinas, D. 2007. A conceptual framework for business intelligence based on activities 
monitoring systems. Intelligent Enterprise. 1(1): 65-80.

Franklin, M.; Halevy, A.; Maier, D. 2005. From Databases to Dataspaces: A New Abstraction for Information Management. ACM Sigmod Record. 34(4): 27-33.

Giovinazzo, W. 2009. BI: Only as Good as its Data Quality. Information Management Special Reports. [interaktyvus]. [žiūrèta 2014-04-22]. <http://www.informationmanagement.com/specialreports/2009_157/ business_intelligence_bi_data_quality_ governance_decision_making-10015888-1. html?pg=1>.

Göres, J., et al. 2009. GEM: A generic visualization and editing facility for heterogeneous metadata. Computer Science Research and Development. 24: 119-135.

Göres, J.; Dessloch, S. 2007. Towards an integrated model for data, metadata, and operations. Business, Technologie und Web. 212-226.

Gontar, Z. 2011. Some remarks on SAS approach to the concept of business intelligence competency center. Information Systems in Management. XIII: 51-66.

Hallett, P. 2004. Metadata Manifesto: Integration, Reconciliation and Change of Enterprise Metadata. SchemaLogic.

Halevy, A. Y., et al. 2005. Enterprise Information Integration: Successes, Challenges and Controversies. ACM Sigmod Record. 778-787.

Hassanien, A. E., et al. 2009. Foundations of Computational Intelligence. Berlin: Springer, Vol. 1.

Hassine-Guetari, S. B.; Laboisse, B. 2011. Managing Multisource Database: Between Theory and Practice. The International Conference on Information Quality, p. 507521.

Hert, A. C. 2004. The Strategic Role of Metadata: How Active Metadata Management Enables Competitive Advantage. SchemaLogic. 6 p.

Hinkelmann, K.; Merelli, E.; Thönssen, B. 2010. The Role of Content and Context in Enterprise Repositories. The 2nd International Workshop on Advanced Enterprise Architecture and Repositories, $13 \mathrm{p}$.
Hristov, H. 2012. Choosing Approach for Data Integration. The Sixth International Conference ISGT'2012, Sofia, Bulgaria, p. 98-113.

Hüner, K. M.; Otto, B.; Österle, H. 2011. Collaborative management of business metadata. Journal of Information Management. 31(4): 366-373.

Inmon, W. H.; O’Neil, B.; Fryman, L. 2008. Business Metadata: Capturing Enterprise Knowledge. Morgan Kaufmann Publishers, Burlington.

ISO, 2009. ISO 23081-2:2009. Information and documentation - Managing metadata for records - Part 2: Conceptual and implementation issues.

Jain, S.; Thomson, B. 2013. Data Lineage: An Important First Step for Data Governance. BeyeNETWORK. [interaktyvus]. [žiūrèta 2014-04-24]. <http://www.b-eye-network. com/view/17023>.

Jiang, B. 2012. Metathink: An Enterprise-Wide Single Version of the Truth, and Beyond. BeyeNETWORK. [interaktyvus]. [žiūrèta 2014-04-24]. <http://www.b-eye-network. com/view/16538>.

Jucevičius, R.; Ilonienè, J. 2009. Žinių organizacijos kompetencijos: valdymo modelių perspektyva. Ekonomika ir vadyba. 14: 778-793.

Jurkowski, G.; Slowinski, B. 2007. IT Applications and specific goal of EAI technologies in SME. Applied Computer Science. 3(1): 7-22.

Kiauleikis, V.; Kiauleikis, M. 2005. Duomenų integravimo procesai ir jų modeliavimas. Informacijos mokslai. 34: 155-159.

Kilpeläinen, T. 2007. Business Information Driven Approach for EA Development in Practice. The 18th Australasian Conference on Information Systems, p. 447-457.

Kilpeläinen, T.; Nurminen, M. 2007. Applying Genre-Based Ontologies to Enterprise Architecture. The 18th Australasian Conference on Information Systems, p. 468-477.

Kutvonen, L. 2008. Tools and infrastructure facilities for controlling nonfunctional properties in inter-enterprise collaborations. The Enterprise Computing Conference, p. 43-50. 
Loshin, D. 2012. Business Analytics: The Importance of Semantic Metadata Processes. BeyeNETWORK. [interaktyvus]. [žiūrèta 2014-04-21]. <http://www.b-eyenetwork.com/view/15948>.

Marotta, A., et al. 2010. Reliability Models for Data Integration Systems. Simulation Methods for Reliability and Availability of Complex Systems, 123-144.

Manegold, S.; Kersten, M. L.; Boncz, P. A. 2009. Database Architecture Evolution: Mammals Flourished long before Dinosaurs became Extinct. VLDB. 2(2): 1648-1653.

Mhashilkar, K.; Sarkar, J. 2009. Information Integration: Metadata Management Landscape. TATA Consultancy Services. 34 p.

Miniotaite, I.; Zalieckaite, L. 2011. Ataskaitų generavimo priemonių taikymas bankuose. Informacijos mokslai. 58: 110-125.

Molholm, K. N. 2006. Standards and interoperability. Information Services And Use. 26: 29-37.

Mödritscher, F.; Hoffmann, R.; Klieber, W. 2007. Integration and Semantic Enrichment of Explicit Knowledge through a Multimedia, Multi-source, Metadata-based Knowledge Artefact Repository. I-Know '07, Graz, Austria, p. 365-372.

Nagy, I. M.; Tolea, E. E. 2011. A Metamodel for Manipulating Business Knowledge Within a Data Warehouse. The 6th International Conference on Virtual Learning, p. 254260.

Nidumolu, R.; Prahalad, C. K.; Rangaswami, M. R. 2009. Why Sustainability Is Now the Key Driver of Innovation. Harvard Business Review. 87(9): 56-64.

Ong, Y. L.; Siew, P. .; Wong, S. F. 2011. A FiveLayered Business Intelligence Architecture. Communications of the IBIMA. $11 \mathrm{p}$.

Pant, P. 2009a. Business Intelligence: How to build successful BI strategy. Deloitte Development LLC. 19 p.

Pant, P. 2009b. Essential Components of a Successful BI Strategy. Information Management. 5 p.

Qin, J.; Prado, J. C. 2006. The semantic and syntactic model of metadata. Alfabetização
Digital e Accesso ao Conhecimento. 4: 143156.

Rahman, N.; Marz, J.; Akhter, S. 2012. An ETL Metadata Model for Data Warehousing. Computing and Information Technology. 20(2): 95-111.

Rudzkiené, V.; Kanopka, A. 2011. Tinkliniu verslo ir informaciniu sistemu modeliu konstravimo ir derinimo metodologiniai aspektai. XV kompiuterininkų konferencijos mokslo darbai, p. 161-174.

Schmidt, A.; Otto, B. 2008. A method for the identification and definition of information objects. The International Conference on Information Quality, p. 214-228.

Shankaranarayanan, G.; Even, A.; Watts, S. 2006. The role of process metadata and data quality perceptions in decision making: an empirical framework and investigation. Journal of Information Technology Management. 17 (1): 50-67.

Stankevičiene, J., et al. 2007. Data Management in Modern Organization: the Aspect of Project Designing. Engineering Economics. 1(51): 91-102.

Stary, C.; Neubauer, M.; Oppl, S. 2010. Interactive Management of Change. The International Conference on Knowlegebased Economy and Global Management, $19 \mathrm{p}$.

Sen, A. 2004. Metadata management: past, present and future. Decision Support Systems. 37(1): 151-173.

Taylor, J. 2004. Enterprise Information Integration: A New Definition. Information management, $3 \mathrm{p}$.

Verbitskiy, Y.; Yeoh, W. 2011. Data quality management in a business intelligence environment: from the lens of metadata. The 16th International Conference on Information Quality, p. 435-447.

Verbitskiy, Y.; Yeoh, W.; Koronios, A. 2009. An Empirical Research into Metadata of Business Intelligence Systems. The Workshop on Advances in Intelligent Computing, p. 43-51.

Vnuk, L.; Koronios, A.; Gao, J. 2012. Enterprise metadata management: identifying success 
factors for implementing managed metadata environments. The 16th Pacific Asia Conference on Information Systems, $12 \mathrm{p}$.

Wik, P. 2011. Service-Oriented Architecture and Business Intelligence. Service Technology Magazine, $18 \mathrm{p}$.

Yan, Z., et al. 2013. Actively Soliciting Feedback for Query Answers in Keyword Search-Based Data Integration. VLDB. 6(3): 205-216.

Yeoh, W.; Koronios, A. 2010. Critical Success Factors for Business Intelligence Systems. Journal of Computer Information Systems, 50(3): 23-32.

Zhang, G.; Jia, S.; Wang, Q. 2010. Construct Ontology-based Enterprise Information Metadata Framework, Journal of Software. 5(3): 312-319.

Асадуллаев, С. 2009. Данные, метаданные и НСИ: тройная стратегия создания хранилищ данных [interaktyvus]. [žiūrèta 2014-04-22]. <http://www.ibm.com/developerworks/ru/library/r-nci/index.html $>$.

Асадуллаев, С. 2010. Управление качеством данных с помощью IBM Information Server [interaktyvus]. [žiūrèta 2014-04-20]. $<$ http://www.ibm.com/developerworks/ru/ library/sabir/inf_s/>.

Богданов, В. В.; Куликов, Д. Д. 2007. Интеграция систем автоматизированной подготовки производства в едином информационном пространстве. Научнотехнический вестник Санкт-Петербургского государственного университета информационных технологий, механики и оптики. 38: 202-207.

Бубарева, О. А.; Попов, Ф. А. 2009. Использование интеграции информации для анализа несопоставимых источников данных в информационно-управляющих системах. VIII Международная конференция „Единая образовательная информационная среда: проблемы и пути развития“, с. 136-137.

Булгаков, С. В.; Корнаков, А. Н. 2010. Основы интегрированного управления предприятием. Вестник Московского государственного областного универсиmema. 1: 104-107.
Вигурский, К. В.; Пивоваров, М. С. 2008. O некоторых вопросах в области метаданных. „Интернет и современное общество“: XI Всероссийская объединенная конференция, с. 38-39.

Егошина, А. А.; Вороной, А. С. 2011. Повышение эффективности извлечения информации из слабо структурированных источников на основе метаданных и базы знаний. Інформатика, кібернетика та обчислювальна техніка. 13 (185): 44-47.

Еркимбаев, А. О.; Зицерман, В. Ю.; Кобзев, Г. А. 2010. Метаданные в задачах систематизации ресурсов по свойствам веществ и материалов. Сборник трудов „Интеллектуализация информационного поиска, скантехнологии и электронные библиотеки“, с. 60-63.

Завьялова, Н. Б. 2011. Методы и инструменты в решении задач стратегического менеджмента. Известия РЭУ им. $Г$. В. Плеханова. 3(3): 50-59.

Замятина, Е. Б., и др. 2008. Интеграция информационных систем и систем имитационного моделирования на основе многоуровневых моделей. Сборник трудов „Математика программных систем“", с. 12-23.

Замятина, Е. Б.; Лядова, Л. Н.; Сухов, А. О. 2013. О подходе к интеграции систем моделирования и информационных систем на основе DSM-платформь MetaLanguage. IV Международная научно-техническая конференция „Технологии разработки информационных систем", с. 61-70.

Карабанова, Г. Д. 2012. Концептуальная модель корпоративной интегрированной системы управления. Вестник СанктПетербургского университета. 5(1): 193-198.

Кашников, А.; Лядова, Л. 2011. Интеграция гетерогенных источников данных на основе рекурсивной декомпозиции. Information Technologies and Knowledge. 3(5): 274-284.

Киреева, О. В. 2008. Проблемы информационного обеспечения процесса управления современными предприятиями. Управленческий учет. 7: 45-53. 
Климов, В. В. 2011. Оптимизация кросссистемной интеграции бизнес-процессов. Экономика ИТ и инноватика: интеграчия бизнеса и процессов, с. 35-43.

Кочеров, М.С.; Филатова,Н.Н.2007. Вопросы проектирования распределенных БД с метаданными. Сборник материалов НПК „Информационные технологии в профессиональной деятельности и научной работе“, с. 254-258.

Ланин, В.; Лядова; Л. Н.; Цыбин, А. 2012. Технология создания документ-ориентированных систем, основанных на метамоделировании. Information Technologies and Knowledge. 6(2): 184-199.

Лядова, Л. Н. 2008. Метамоделирование и многоуровневые метаданные как основа технологии создания адаптируемых информационных систем. Information Technologies and Knowledge. 2: 125-132.

Лядова, Л. Н. 2009. Использование метаданных и метамоделирования для разработки адаптируемых систем мониторинга. Интеллектуальные системы (AIS'09). 1: 526-531.

Лядова, Л. Н. 2012. Метамоделирование как основа средств оперативной разработки профессионально-ориентированных информационных систем. Математика программных систем. 9: 20-32.

Микляев, И. А. 2010. Концепция разработки матричной универсальной базы данных с поддержкой древовидной структуры единицы информации и её универсального приложения. Вестник Воронежского государственного универcumema. 2: 101-108.

Микляев, И. А. 2013. Универсальная база данных с выделенной тяжёлой информацией в справочные сущности на основе синтеза метаинформации и данных. Вестник Воронежского государственного университета. 1: 126-135.

Михайлов, И. С. 2009. Исследование и разработка методов и программных средств обеспечения структурной и семантической интероперабельности инбормаицонных систем на основе метамоделей. 11 нац. конф. по искусственному интеллекту. 2: 207-209.

Полотнюк, И. С. 2005. Метаданные как базис интеграции. Вестник компьютерных и информационных технологий. № 12.

Поляков, А. Н., и др. 2013. Разработка программных средств виртуальной интеграции распределенных источников данных для создания масштабных информационных инфраструктур профессионального назначения. Информатика и системы управления. 3: 152-160.

Рычков, А. Ю. 2009. Управление бизнеспроцессами в системах, основанных на метаданных. Вестник Пермского универcumema. 3(29): 153-156.

Семенов, С. П.; Татаринцев, Я. Б. 2011. Обесечение слабой связанности интегрируемых информационных систем посредством асинхронного обмена сообщениями через сервисную шину. Вестник Югорского государственного универсиmema. 3(22): 45-50.

Султанова, 3. 2011. Метаданные как современный атрибут официальной статистики. Экономика и статистика. 3: 4246.

Хитрова, Т. И. 2010. Интеграция информационных ресурсов. Известия Иркутской государственной экономической академии. 5: 286-289.

\title{
INTEGRATION OF ACTIVITY DATA: PROBLEMS, PECULIARITIES AND THE IMPORTANCE OF METADATA
}

\author{
Grazina Kalibataite
}

Kaunas University of Technology, Lithuania

Summary. This article explores the integration process of an enterprise data from the viewpoint of metadata management. This article also presents modern problems of data 
integration, various important aspects of integrated information management and new integration needs. Moreover, the reasoning on the metadata used for the administration of data integration, and metadata approach (integration and architectural capabilities), which easily allows collecting, processing, organising and, most importantly, integrating activity information from different data sources and applications. Lastly, this paper presents an empirical research in the enterprise of the data integration view (i.e. in the domain of human resource information management). The current information management situation of human resources is also graphically revealed and shown in this paper. This is a good practical tool for the development and optimisation of human resource processes and data integrations.

Today, when many enterprises do not live and exist without data integration, the integration quality (of activity information process and information) could be improved by using more flexible methods and effective decisions of data integration. Therefore, integration has to change and new integration activities should be developed or the existing ones should be changed, e.g. choosing (or creating their own) specific management tools, practices or techniques of integration that help defining, identifying and understanding the integration processes and the content of integration. Otherwise to provide the necessary knowledge on integrated business objects and data, whereas ensure trust of data users in the integrated data. This adequate form of integration management (and information creation) can be suitable to support the environment of today's business world (i.e. when the complexity of integration increases and there is a thriving requirement for information integration needs), integration based on (controlled by) activity (enterprise) metadata and its management.

This research showing that metadata - an essential element of data quality and safety integrity - can help constantly optimise and improve the information services and adapt them to the real (local) business needs of the enterprise. However, it is a daunting task - the metadata requirements are difficult to obtain and organise, because metadata is often very specific to different enterprise sectors, perceived differently and always need to be collected and exploited. Moreover, one must need and be able to deeply understand the semantics of the data, the scheme of the data source and to describe the schemes ( $a$ unique metadata). One also needs to work with several types of applications or tools (with modelling, integration, acquisition, storage, analysis, provision). Despite these and other difficulties in the work discussed, the necessity fact - the integration process needs to be provided with metadata information elements (e.g. with domain knowledge of activity/process, knowledge of activity expert). This is so because without metadata information, data integration cannot be designed effectively and qualitatively.

Keywords: data integration, metadata, interoperability, information systems, integration architecture, activity model, human resources information management, modelling, data management. 